\title{
INSURING LANDSLIDES: AMERICA'S UNINSURED NATURAL CATASTROPHES
}

\begin{abstract}
Christopher C. French*
Landslides occur in all fifty states and cause approximately $\$ 3.5$ billion in property damage annually. Yet, in America, "all risk" homeowners and commercial property insurance policies exclude coverage for landslides, and there is only limited availability of expensive, stand-alone "named peril" insurance policies that cover landslide losses. Consequently, the affected homeowners are often left financially devastated-homeless with a mortgage to pay on an unsaleable piece of property.

This Article analyzes the problem of insuring landslide losses in America and proposes ways to help solve it. It describes both historical and recent landslide events. It discusses the insurance industry's response to the problem of insuring landslides, including the theoretical justifications insurers historically have used to successfully exclude coverage for landslides-adverse selection, moral hazard and correlated risks. It also considers how other countries such as Belgium, France, New Zealand, Norway, Romania, Switzerland, Iceland and Australia address the issue of insuring landslide losses. It concludes by offering two ways to transform the insurance market for landslide losses in America.
\end{abstract}

\section{TABLE OF CONTENTS}

INTRODUCTION

I. THE NATURE AND HISTORY OF LANDSLIDES IN AMERICA ……................69

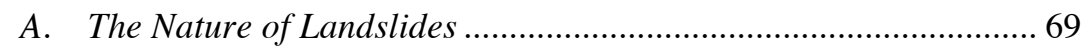

B. The Prevalence of Landslides ....................................................... 70

II. INSURERS' EXCLUSION OF COVERAGE FOR LANDSLIDES ...................... 71

A. The Landslide Exclusion .............................................................. 71

B. The Adverse Selection, Moral Hazard and Correlated Risk

Concerns That Led to the Landslide Exclusion ........................... 74

1. Adverse Selection ............................................................ 74

* Christopher C. French is a Visiting Assistant Professor at Penn State Law; J.D., Harvard Law School; B.A., Columbia University. The author gratefully acknowledges the legal research contributions of Kimberli Kelmor, Kelsie Massini, David Paterson, and Penelope Scudder to this Article. The author also would like to thank Ken Abraham, Jay Feinman, David Kaye, Kit Kinports, Leo Martinez, Stephen Ross, and the participants in workshops held at Penn State Law School and Florida State Law School for providing thoughtful comments on the issues addressed in the Article or earlier drafts of the Article. 


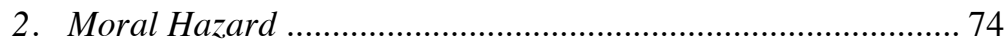

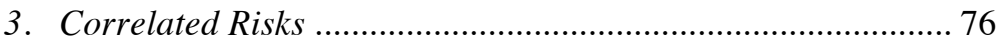

C. Courts' Inconsistent Applications of the Landslide Exclusion ...... 78

D. The Limited Availability of Coverage for Landslides Under Stand-Alone Surplus Policies........................................................ 79

III. Potential Solutions to THE LANDSLIDE INSURANCE PROBLEM ...... 82

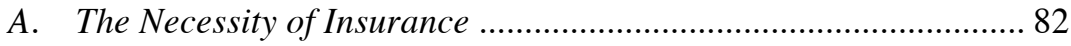

B. State Action to Remove the Landslide Exclusion from Policies .... 83

C. State-Sponsored Landslide Insurance Programs ............................ 84

D. Insurance for Landslide Losses in other Countries ........................ 89

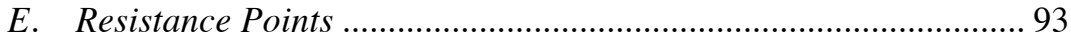

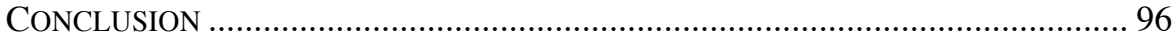

\section{INTRODUCTION}

At 10:37 a.m., a few miles east of Oso, a town near Seattle, Washington, a woman heard a roar that sounded like an airplane crash. ${ }^{1}$ A mountain of mud twenty feet high was "racing like 150 miles an hour [sic] across the far end of the valley." She had time to exclaim, "Oh my God," before the wall of mud destroyed her house. ${ }^{3}$ Somehow she survived and dug her way out of the "tangled sludge." ${ }^{4}$ More than forty people perished. ${ }^{5}$ In all, the landslide was nearly one mile wide and engulfed forty-nine homes and businesses. ${ }^{6}$ The clean-up costs and damage have been estimated at more than $\$ 40$ million. ${ }^{7}$ The Oso Landslide is the second-deadliest natural disaster in the history of the State of

${ }^{1}$ Mike Lindblom \& Mike Carter, Survivor Tells of Loud Crack, Wall of Mud, House in 'Sticks', SeATtle Times (Mar. 22, 2014, 8:11 PM), http://old.seattletimes.com/ht ml/localnews/2023202905_mudslidevictimsxml.html [https://perma.cc/J8WU-ZLVU]; Elizabeth Weise \& Elizabeth Wiley, Oso Landslide Hit Fast, Hard and with No Warning, USA TODAY (Mar. 30, 2014, 10:29 PM), http://www.usatoday.com/story/news/nation/2014/03/ 28/oso-landslide-seismic-records-two-slides-no-warning/7019249/ [https://perma.cc/U7YQTD9A].

${ }^{2}$ Weise \& Wiley, supra note 1 .

${ }^{3} I d$.

${ }^{4}$ Lindsey Bever, The Fatal Mudslide in Washington: What Was It Like?, WASH. Post (Mar. 24, 2014), https://www.washingtonpost.com/news/morning-mix/wp/2014/03/24/the-fatalmudslide-in-washington-what-was-it-like/ [https://perma.cc/W3EW-59SP].

5 See Media Update, Snohomish Cty. Med. Exam'rs Office (May 27, 2014, 7:30 AM), http://snohomishcountywa.gov/ArchiveCenter/ViewFile/Item/3855 [https://perma.cc/D24DQG28].

${ }^{6}$ Seattle Times Staff, 14 Dead; 176 Reports of People Missing in Mile-Wide Mudslide, SEATtle Times (Mar. 24, 2014, 11:36 AM), http://old.seattletimes.com/ht $\mathrm{ml} /$ localnews/2023215066_mudslidemondayxml.html?mbaseid=2023215066 [https://perma. $\mathrm{cc} / \mathrm{XCV} 4-3 \mathrm{P} 8 \mathrm{~F}]$.

7 Oso Mudslide: Washington State Disaster Site Yields More Dead, BBC News (Apr. 2, 2014) [hereinafter BBC NEws], http://www.bbc.com/news/world-us-canada-26855649 [http s://perma.cc/49WL-M53S]. 
Washington. ${ }^{8}$ Not one of the homes and businesses had insurance that covered landslides. ${ }^{9}$

Landslides occur in all fifty states and cause approximately $\$ 3.5$ billion in property damage per year. ${ }^{10}$ They occur regularly in the coastal and mountainous areas of California, Oregon, and Washington, the intermountain central western states, and the mountainous and hilly regions of the eastern United States. ${ }^{11}$

How is it possible that not a single home or business destroyed by the Oso Landslide had insurance that covers landslide losses? Like several other types of natural catastrophes such as floods and earthquakes, landslides are excluded from coverage under "all risk" homeowners and "all risk" commercial-property insurance policies. ${ }^{12}$ Not only are landslides specifically excluded from coverage under "all risk" property policies, insurance that covers landslides is not even available for purchase in many states. ${ }^{13}$

Why are landslides, one of the biggest and most expensive disasters that can impact a person's home or business, excluded from coverage under "all risk" property policies? Insurers have advanced three principal theoretical bases to justify excluding coverage for natural catastrophes: (1) adverse selection, (2) moral hazard, and (3) correlated risks. ${ }^{14}$ The theory of adverse selection is that

\footnotetext{
${ }^{8}$ Austin Jenkins, Oso Landslide Could Be Deadliest Disaster in Washington State History, NW News NeTwORK (Mar. 27, 2014), http://nwnewsnetwork.org/post/oso-landslide-couldbe-deadliest-disaster-washington-state-history [https://perma.cc/7MTU-EVM7].

9 Caitlin Bronson, "Absolutely Heartbreaking" Lack of Coverage for Wash. Landslide Victims, INS. Bus. AM. (Mar. 26, 2014), http://www.ibamag.com/news/catastrophe/absolutelyheartbreaking-lack-of-coverage-for-wash--landslide-victims-17666.aspx [https://perma.cc/Q XJ9-73FX].

${ }^{10}$ U.S. Geological Survey, Landslide Types and Processes (2004); Rob Risley, Comment, Landslide Peril and Homeowners' Insurance in California, 40 UCLA L. REV. 1145, 1146-47 (1993); Landslides in the United States Since 2007, NAT'L GEOGRAPHIC (Apr. 23, 2014), http://news.nationalgeographic.com/news/2014/04/140422-surveying-american-land slides-interactive/ [https://perma.cc/9U68-QLNK].

${ }^{11}$ U.S. Geological Survey, supra note 10; Don Hopey, The Pittsburgh Area Is Prone to Landslides, and Human Activity Often Makes Them Worse Down Town, PosT-GAZETTE.COM (Aug. 6, 2001), http://old.post-gazette.com/healthscience/20010806landslidemainhealth 6p6.asp [https://perma.cc/K3ZN-XH2G] (the Pittsburgh area has more than 15,000 documented landslides).

${ }^{12}$ See, e.g., Brian Mattis, Earth Movement Claims Under All Risk Insurance: The Rules Have Changed in California, 31 SAnta Clara L. Rev. 29, 36 (1990) (citing State Farm Fire \& Cas. Co.'s Homeowners Policy Special Form 3, p. 7, Form FP-7103); Ins. Servs. Office, Inc., Causes of Loss - Broad Form No. CP 102006 07, at 2 (2007). "All risk" property insurance covers all risks of loss unless the peril is specifically excluded. See PETER J. KALIS et Al., Policyholder's Guide to the Law of Insurance Coverage § 13.02[B] (Supp. 2015).

13 See infra Parts II.A and II.D.

${ }^{14}$ See, e.g., Christopher C. French, Insuring Floods: The Most Common and Devastating Natural Catastrophes in America, 60 VILL. L. Rev. 53, 54 (2015).
} 
only the people most likely to have losses will purchase insurance. ${ }^{15}$ Moralhazard theory posits knowledge that insurance will cover any losses makes a person who has insurance less likely to take care to avoid losses ${ }^{16}$ Correlated risks are risks that may result in numerous losses in the same area at approximately the same time. ${ }^{17}$ Insurers have claimed that the inability to predict when correlated risks will result in losses makes it impossible to set actuarially sound premiums. ${ }^{18}$

15 Adverse selection is "the disproportionate tendency of those who are more likely to suffer losses to seek insurance against those losses.” Kenneth S. Abraham \& Lance Liebman, Private Insurance, Social Insurance, and Tort Reform: Toward a New Vision of Compensation for Illness and Injury, 93 Colum. L. REV. 75, 102 n.82 (1993); see Tom Baker, Containing the Promise of Insurance: Adverse Selection and Risk Classification, 9 CONN. INS. L.J. 371, 373-75 (2003). Some critics of the concept of adverse selection have argued that insurers' alleged concerns regarding the impact that adverse selection actually has on policyholders' behavior are overblown. See, e.g., Peter Siegelman, Essay, Adverse Selection in Insurance Markets: An Exaggerated Threat, 113 YALE L.J. 1223, 1223 (2004).

${ }^{16}$ Moral hazard is the term used to describe the phenomenon that a person will have a "tendency to take fewer precautions in the presence of insurance." Adam F. Scales, The Chicken and the Egg: Kenneth S. Abraham's "The Liability Century," 94 VA. L. REV. 1259, 1263 (2008) (book review). Judge Easterbrook has described the theory underlying the concept by stating that "[o]nce a person has insurance, he will take more risks than before because he bears less of the cost of his conduct." W. Cas. \& Sur. Co. v. W. World Ins. Co., 769 F.2d 381, 385 (7th Cir. 1985). The term "moral hazard" also generally encompasses situations where "[a] person ... deliberately causes a loss ... [or] exaggerates the size of a claim to defraud an insurer." MARK S. DORFMAn, InTROduction TO Risk MANAGEMENT AND INSURANCE 480 (8th ed. 2005). Numerous scholars have written articles regarding moral hazard and offered similar descriptions of the concept. See, e.g., Scott E. Harrington, Prices and Profits in the Liability Insurance Market, in FOUNDATIONS OF INSURANCE ECONOMICS: ReAdings in ECONOMics AND FinAnCE Liability: Perspectives AND Policy 626, 631 (George Dionne \& Scott Harrington eds., 1992) ("Moral hazard is the tendency for the presence and characteristics of insurance coverage to produce inefficient changes in buyers' loss prevention activities, including carelessness and fraud ..."); ROBERT H. JERRY, II \& DOUGLAS R. RICHMOND, UNDERSTANDING INSURANCE LAW 12 (5th ed. 2012) (“[T]he existence of insurance can have the perverse effect of increasing the probability of loss.... [t]his phenomenon is called moral hazard."); George L. Priest, The Current Insurance Crisis and Modern Tort Law, 96 YALE L.J. 1521, 1547 (1987) ("Moral hazard refers to the effect of the existence of insurance itself on the level of insurance claims made by the insured. . . Ex ante moral hazard is the reduction in precautions taken by the insured to prevent the loss, because of the existence of insurance."); Gary T. Schwartz, The Ethics and the Economics of Tort Liability Insurance, 75 CoRnell L. REV. 313, 338 n.117 (1990) (“'Moral hazard' is sometimes distinguished from 'morale hazard,' the former referring to deliberate acts like arson, the latter to the mere relaxation of the defendant's discipline of carefulness.").

${ }^{17}$ Correlated risks are situations where numerous people in concentrated areas have essentially the same risk of the same type of loss occurring at approximately the same time. French, supra note 14, at 63; see also Véronique Bruggeman et al., Insurance Against Catastrophe: Government Stimulation of Insurance Markets for Catastrophic Events, 23 DUKE EnvTl. L. \& Pol'y F. 185, 187 (2012); J. David Cummins, Should the Government Provide Insurance for Catastrophes?, FED. RES. BANK ST. LouIS REV., July 2006, at 342-43; Adam F. Scales, A Nation of Policyholders: Governmental and Market Failure in Flood Insurance, 26 Miss. C. L. REV. 3, 10-11 (2006).

${ }^{18}$ See Bruggeman et al., supra note 17. 
When a risk simultaneously involves adverse selection, moral hazard, and correlated risks, conventional wisdom says the risk is one that insurers cannot or should not cover. Landslides are such a risk, according to this conventional wisdom. First, only the people most likely to suffer landslide losses will purchase a policy that covers only landslides. Thus, the pool of insured persons ("insureds") that would pay premiums to cover landslide losses would be relatively small, and the premiums would need to be very high, frustrating the riskspreading function of insurance. Second, under moral hazard theory, a homeowner who has insurance would take fewer measures to avoid or minimize landslide losses, thereby increasing the likelihood and severity of landslide losses. Third, landslide losses are correlated risks because the losses associated with landslide events tend to occur in concentrated geographic locations at about the same time.

This Article questions the soundness of the three justifications for excluding coverage for landslide losses under "all risk" property policies. Once the limited force of these justifications is recognized, two solutions to the problem become apparent: simply eliminate the exclusion from homeowners' policies, or establish state-sponsored landslide insurance programs.

Today, homeowners insurance is a classic example of a type of insurance for which adverse selection is of little concern because the pool of insureds across which the risk of loss is spread is so large. Because homeowners insurance is effectively mandatory in America, approximately 95 percent of homeowners buy homeowners insurance. ${ }^{19}$ One cannot get a federally guaranteed mortgage without homeowners insurance. ${ }^{20}$ Consequently, if landslide losses were covered by homeowners insurance, then the pool of insureds across which the risk of loss would be spread would be so enormous that adverse selection regarding the purchase of insurance to cover landslide losses would not be an issue.

Similarly, moral-hazard concerns regarding landslide losses are actually quite low because of the extreme danger landslides present and the enormous disruption and inconvenience a landslide causes a homeowner. In addition to the risk of bodily injury or death, a homeowner can lose items of irreplaceable sentimental value when a landslide hits and the homeowner often becomes homeless. Thus, people have ample incentives to avoid landslide losses regardless of whether they have insurance. Consequently, it stands to reason that building codes and land development restrictions are a better means of avoiding

19 INS. INFO. INST., HOMEOWNERS AND RENTERS INSURANCE, http://www.iii.org/facts_statis tics/homeowners-and-renters-insurance.html [https://perma.cc/72MF-P9BY] (last visited May 31, 2016); see also Scales, supra note 17, at 18.

${ }^{20}$ See What is Homeowner's Insurance? Why is Homeowner's Insurance Required?, Consumer Fin. Prot. Bureau [hereinafter Consumer Fin. Prot. Bureau], http://www .consumerfinance.gov/askcfpb/162/what-is-homeowners-insurance-why-is-home owners-insurance-required html [https://perma.cc/C3UX-EGBG] (last visited July 5, 2016). 
or preventing landslide losses than excluding coverage for landslides under "all risk" property policies is.

Also, landslides are not correlated risks like earthquakes and floods, which can impact hundreds or thousands of people in the same geographic area at approximately the same time. ${ }^{21}$ Notwithstanding the exceptional size of the Oso Landslide, most landslides are geographically isolated events that impact only a few people when they occur. ${ }^{22}$

In addition, unlike when landslide losses are insured under stand-alone policies, the financial risks to insurers associated with covering landslide losses would be reduced, if not entirely eliminated, if they were covered under "all risk" homeowners policies. That is because the capital reserves from which insurers would pay losses would be created from a pool of capital created by the approximately sixty-nine million premium-paying homeowners ${ }^{23}$ whose properties are located throughout the country rather than from just the few thousand people who currently buy stand-alone landslide insurance and primarily live in areas at a high risk for landslides.

In addition, due to the growth of global reinsurance and the sale of catastrophe bonds during the past few decades, ${ }^{24}$ the financial risk to any individual insurer from a landslide event can be further reduced. With such risktransferring mechanisms, other insurers and investors can share an individual insurer's risk of loss.

This Article proceeds in three parts. Part I describes the nature and history of landslides. Part II discusses the landslide exclusion and the theoretical rationales used to justify insurers' refusal to cover landslides. Part III discusses the arguments in favor of and against eliminating the landslide exclusion currently contained in "all risk" property policies. Part III also examines how other countries such as Belgium, France, New Zealand, Norway, Romania, Switzer-

${ }^{21}$ Correlated Risks, WORLD FINANCE (June 30, 2010) http://www.worldfinance.com/ home/risk-encyclopaedia/correlated-risks [https://perma.cc/CQ3D-865A].

${ }^{22}$ See, e.g., LANDSLIDES: Evaluation AND STABILIZATION 126 (Willy A. Lacerda et al. eds., 2005) (stating over 500 landslides studied between 1954 and 2001 had an average size of just over 500 square meters); LAWRENCE R. WALKer \& AARON B. ShiELs, LANDSLide ECOLOGY 62 (2013) (stating the average size of 281 landslides studied was 100 square meters); Risley, supra note 10, at 1174 ("Although relative earthquake risk among homeowners will vary with construction and soil type, earthquake peril threatens nearly every California homeowner. ... Landslide risk is more site-specific than earthquake risk ..."). To contrast landslides with correlated risks, consider that the Oso Landslide, one of the worst landslides in American history, caused approximately $\$ 42$ million in damages while Hurricane Katrina caused over $\$ 100$ billion. See Christine A. Klein \& Sandra B. Zellmer, Mississippi River Stories: Lessons from a Century of Unnatural Disasters, 60 SMU L. REv. 1471, 1499 (2007); BBC NEWs, supra note 7.

${ }^{23}$ See French, supra note 14, at 75.

${ }^{24}$ See generally $\mathrm{Al}$ Yoon \& Leslie Scism, Investors Embrace 'Catastrophe Bonds', WALL ST. J. (Apr. 23, 2014, 6:44 PM), http://www.wsj.com/articles/SB1000142405270230404990 4579517710350913016 [https://perma.cc/TVS8-4AGR]. 
land, Iceland, and Australia have addressed the issue of insuring landslide losses. This article concludes that the elimination of the landslide exclusion from homeowners policies would increase the number of American homeowners with coverage for landslide losses from a few thousand to sixty-nine million without causing undue financial hardship to insurers. Another more expensive, but potentially satisfactory, way of addressing the problem would be through the creation of state-sponsored landslide insurance programs. Under both proposals, the current problem of uninsured landslide losses in America would be addressed.

\section{THE NATURE AND HISTORY OF LANDSLIDES IN AMERICA}

\section{A. The Nature of Landslides}

The term "landslide" denotes a "wide variety of processes that result in the downward and outward movement of slope-forming materials including rock, soil, artificial fill, or a combination of these" materials. ${ }^{25}$ Although landslides are primarily associated with mountainous regions, they also occur on slopes that are not particularly steep in cases of river bluff failures, collapses of coal mine-waste piles, and roadway and building excavations. ${ }^{26}$ Landslides include "falls" (abrupt movements of masses such as rocks and boulders), earth slides, debris flows, and earthen avalanches such as "mudslides."27

Landslides result from a variety of causes, including earthquakes, volcanic activity, and human activities such as excavation or deforestation, but slope saturation by water is usually the primary cause. ${ }^{28}$ Typically, natural landslides occur after periods of intense rainfall or snowmelt. ${ }^{29}$ The upper layers of soil become unstable due to the weight of the water in the soil. ${ }^{30}$ The downward pull of gravity causes the upper, saturated soil to slip away from the more stable underlying material. ${ }^{31}$ It is often difficult to predict precisely when and where landslides will occur, which means there is often little or no advance warning to the people in the areas where landslides occur. ${ }^{32}$ The Oso Landslide is a deadly example.

25 See U.S. GeOlogical SuRVey, supra note 10.

${ }^{26} I d$.

${ }^{27} I d$.

${ }^{28} I d$.

${ }^{29} I d$.

${ }^{30} I d$.

${ }^{31} I d$.

${ }^{32}$ See, e.g., William Yardley, Water Views with a Hint of Daring and Danger, N.Y. TimES, Feb. 27, 2012, at A11. 


\section{B. The Prevalence of Landslides}

Landslides are not a new problem in America. They are natural phenomena that have occurred for eons, but they are especially damaging and dangerous for areas of the country on or near hillsides and mountains that have been developed..$^{33}$ The area in and around Pittsburgh, Pennsylvania, for example, has had over 15,000 documented landslides. ${ }^{34}$ Oregon has over 46,000 known landslide locations. ${ }^{35}$ In Washington, landslide debris has covered the entire twentymile stretch of railroad track between Everett and Elliott Bay in Seattle at one time or another over the past eighty years, with one hundred landslides occurring along the route in 2011 alone. ${ }^{36}$ California, which accounts for approximately 20 percent of the landslides in America, also has a long history of landslide disasters, causing billions of dollars of damage and numerous deaths. ${ }^{37}$

A map that shows the landslide risk profiles for the various areas of the country is set forth below with the darkest areas depicting the areas with the highest risk: ${ }^{38}$

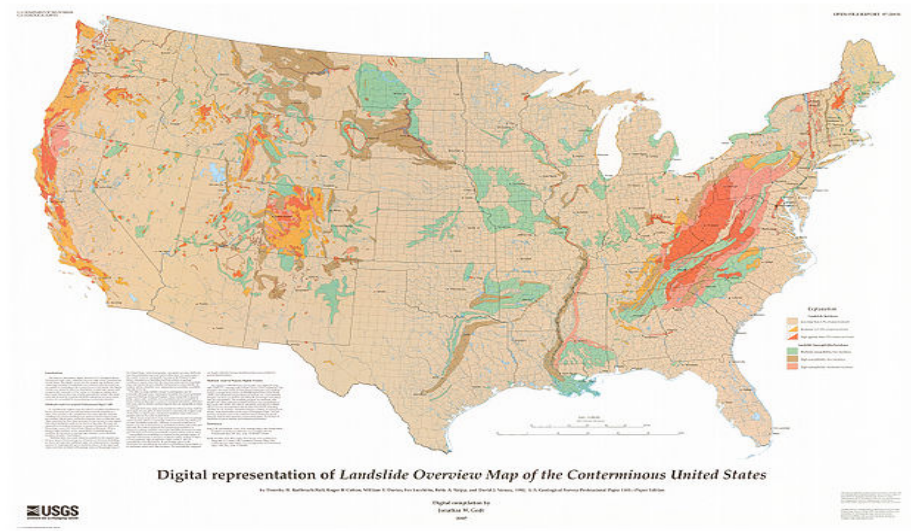

As discussed above, nearly all of the annual $\$ 3.5$ billion landslide-damage loss in the United States is uninsured. ${ }^{39}$ Often, homes are not repaired, and many victims are rendered homeless while facing the prospect of bankruptcy

33 See U.S. GeOlOGICAL SuRVEY, supra note 10.

${ }^{34}$ See Hopey, supra note 11.

${ }^{35}$ Tim Steele, Landslide Database Now Includes 46,000+ Locations, KoIN 6 (Apr. 23, 2014, 6:07 PM), http://koin.com/2014/04/23/landslide-database-now-includes-46000-locations/ [ht tps://perma.cc/CMZ5-ENPW].

${ }^{36}$ Yardley, supra note 32.

37 See, e.g., Samuel Goldberg, Comment, Falling into the Pacific: California Landslides and Land Use Controls, 16 S. CAL. REv. L. \& Soc. JuST. 95, 105-06, 112 (2006); Risley, supra note 10 , at 1147 .

${ }^{38}$ U.S. Geological SuRvey, Landslide Overview Map of the Conterminous United States, NAT'L CTR. ENVTL. INFO., http://www.ngdc.noaa.gov/hazardimages/picture/show/1546 [http s://perma.cc/S6J9-CYJV] (last visited May 31, 2016).

39 Supra Introduction. 
because they remain legally liable for their damaged houses as well as the mortgages. ${ }^{40}$

\section{INSURERS’ EXCLUSION OF COVERAGE FOR LANDSLIDES}

\section{A. The Landslide Exclusion}

Most homeowners policies purport to cover "all risks" of loss except for the specific risks that are expressly excluded.$^{41}$ Historically, prior to the advent of "all risk" property policies, property policies were "named peril" policies that covered only one specified peril. ${ }^{42}$ Following the Great Fire of 1666 in London, the first non-marine named-peril policy was created to cover fire losses. ${ }^{43}$ Beginning in the 1940s and 1950s, insurers began bundling together coverages for multiple named perils into single policies. ${ }^{44}$ Such policies are known as "multi-peril" policies. ${ }^{45}$ As with named peril policies, any perils that were not expressly listed as covered under "multi-peril" policies were excluded. ${ }^{46}$ "All risk" policies evolved from "multi-peril" policies and provide the broadest property coverage available. ${ }^{47}$

For hundreds of years, coverage for the risk of loss due to "earth movement," which includes earthquakes and landslides, generally has been excluded from coverage under the various types of property policies. ${ }^{48}$ The landslide ex-

40 See Sanjay Bhatt, Slide Erased Their Homes, but Maybe Not Their Loans, SEATtLe TimeS

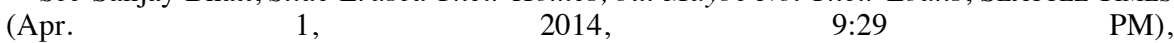
http://seattletimes.com/html/latestnews/2023278858_mudslidefinancialxml.html [https://perma.cc/XR8Z-546R] ("If [the Oso Landslide victims] can't get adequate relief on their mortgages, ... they may pursue bankruptcy to get rid of the debt."); Becky Johnson, Landslide Hazard Maps Axed by State: Risky Slopes in Jackson, Haywood to Remain a Mystery for Now, SMOKY MOUNTAIN NEws (June 29, 2011, 7:25 PM), http://www.smokymoun tainnews.com/news/item/4292-landslide-hazard-maps-axed-by-state-risky-slopes-in-jacksonhaywood-to-remain-a-mystery-for-now [https://perma.cc/9ZHT-CUJX] ("Regular homeowners insurance doesn't cover landslides. Homeowners are out of luck - whether a home is totally flattened or the foundation destabilized due to shifting soil. They can't sell their home, nor will insurance compensate them. Meanwhile, they have to keep paying the mortgage on a house they can't live in. Often, bankruptcy and foreclosure become the only option.").

${ }^{41}$ See, e.g., Jeff Katofsky, Subsiding Away: Can California Homeowners Recover from Their Insurer for Subsidence Damages to Their Homes?, 20 PAC. L.J. 783, 785 (1989) ("In an 'all risk' policy, all losses except those specifically excluded are covered. This is the broadest form of coverage and has been so interpreted by the courts.").

${ }^{42}$ See KALIS ET AL., supra note 12, § 13.02[A][1].

${ }^{43}$ Id.

${ }^{44}$ French, supra note 14, at 60.

${ }^{45}$ See id.

${ }^{46}$ Id ; KALIS ET AL., supra note $12, \S 13.02[\mathrm{~A}]$.

${ }^{47}$ KALIS ET AL., supra note 12, § 13.02[B].

48 See, e.g., Columbia Ins. Co. of Alexandria v. Lawrence, 35 U.S. 507, 518 (1836) (noting the exclusion of coverage for earthquakes under a fire policy); Peters Twp. Sch. Dist. v. 
clusion currently contained in "all risk" homeowners policies is worded the same as or similar to the following: "We do not insure for loss caused directly or indirectly by ... Earth Movement [, which] means . . . landslide, mudslide or mudflow ..." "All risk" commercial-property policies currently contain a similarly worded exclusion for losses caused by landslides:

We will not pay for loss or damage caused directly or indirectly by any of the following.... [l]andslide, including any earth sinking, rising or shifting related to such event; ... Such loss or damage is excluded regardless of any other cause or event that contributes concurrently or in any sequence to the loss. ${ }^{50}$

Hartford Accident \& Indem. Co., 833 F.2d 32, 35 (3rd Cir. 1987) (“[T]he reason for the insertion of the exclusionary clause ... in all risk insurance policies is to relieve the insurer from occasional major disasters which are almost impossible to predict and thus to insure against. There are earthquakes or floods which cause a major catastrophe and wreak damage to everyone in a large area rather than on individual policyholder.") (quoting Wyatt v. Nw. Mut. Ins. Co., 304 F. Supp. 781, 782-83 (D. Minn. 1969)); Powell v. Liberty Mut. Fire Ins. Co., 252 P.3d 668, 672-73 (Nev. 2011) ("Earth movement exclusions were historically included in insurance policies to protect insurance companies from having to pay out on policies when a catastrophic event caused damage to numerous policyholders."); Christopher C. French, The "Ensuing Loss" Clause in Insurance Policies: The Forgotten and Misunderstood Antidote to Anti-Concurrent Causation Exclusions, 13 NEv. L.J. 215, 216-17 (2012).

${ }^{49}$ Ins. SERVs. OfFICE, InC., SAMPle HomeOwners Policy Form No. HO 000305 11, at 12 (2010), reprinted in KenNeth S. Abraham \& Daniel Schwarcz, Insurance LAW AND REGULATION 197 (6th ed. 2015) (emphasis added). The complete wording of a typical "earth movement" exclusion is as follows:

A. We do not insure for loss caused directly or indirectly by ...

2. Earth Movement [, which] means:

a. Earthquake, including land shock waves or tremors before, during or after a volcanic eruption;

b. Landslide, mudslide or mudflow;

c. Subsidence or sinkhole; or

d. Any other earth movement including earth sinking, rising or shifting.

This Exclusion A.2 applies regardless of whether any of the above, in A.2.a through A.2.d, is caused by an act of nature or is otherwise caused.

However, direct loss by fire, explosion or theft resulting from any of the above, in A.2.a through A.2.d, is covered.

Id. Interestingly, insurers added the "ensuing loss" language to the exclusion as a result of adverse court rulings in California regarding the "earth movement" exclusion in which the courts required insurers to cover the losses caused by fires that in turn were caused by the 1906 San Francisco earthquake. See French, supra note 48.

${ }^{50}$ InS. SERVS. OFFICE, INC., CAUSES OF LOSS - SPECIAL Form, COMMERCIAL PROPERTY Form CP 10301012 § B.1.b.2., at 1 (2011) (emphasis added). Insurance Services Office ("ISO”) is an influential organization within the insurance industry comprised of approximately 1400 property and casualty insurers that promulgates standard form insurance policies, including property policies. Hartford Fire Ins. Co. v. California, 509 U.S. 764, 772 (1993). In particular, the organization develops its own standard policy forms and makes them available to its member insurers which then adopt them and present them to state insurance regulators for approval. See, e.g., id. The complete wording of the "earth movement" exclusion contained in typical "all risk" property policies is as follows:

B. Exclusions 
"All risk" property policies that contain landslide exclusions are contracts of adhesion drafted by insurers and then sold on a take-it-or-leave-it basis. ${ }^{51}$ Because "all risk" homeowners policies sold in America generally contain landslide exclusions, homeowners generally cannot buy an "all risk" homeowners policy that does not contain an exclusion for landslides. ${ }^{52}$

1. We will not pay for loss or damage caused directly or indirectly by any of the following. Such loss or damage is excluded regardless of any other cause or event that contributes concurrently or in any sequence to the loss.

b. Earth Movement

(1) Earthquake, including tremors and aftershocks and any earth sinking, rising or shifting related to such event;

(2) Landslide, including any earth sinking, rising or shifting related to such event;

(3) Mine subsidence, meaning subsidence of a man-made mine, whether or not mining activity has ceased;

(4) Earth sinking (other than sinkhole collapse), rising or shifting including soil conditions which cause settling, cracking or other disarrangement of foundations or other parts of realty. Soil conditions include contraction, expansion, freezing, thawing, erosion, improperly compacted soil and the action of water under the ground surface.

But if Earth Movement, as described in b (1) through (4) above, results in fire or explosion, we will pay for the loss or damage caused by that fire or explosion.

(5) Volcanic eruption, explosion or effusion. But if volcanic eruption, explosion or effusion results in fire, building glass breakage or Volcanic Action, we will pay for the loss or damage caused by the fire, building glass breakage or Volcanic Action.

Ins. Servis. Office, Inc., Causes of Loss - Special Form, Commercial Property Form CP 10301012 § B.1., at 1 (2011).

${ }^{51}$ See, e.g., JefFrey W. Stempel, Law of Insurance Contract Disputes $§ 4.06[\mathrm{~b}]$, at 437 (2d ed. Supp. 2005) ("In a sense, the typical insurance contract is one of 'super-adhesion' in that the contract is completely standardized and not even reviewed prior to contract formation."); Michelle Boardman, Insuring Understanding: The Tested Language Defense, 95 IOWA L. REV. 1075, 1091 (2010) (describing the "hyperstandardization" of insurance policies); James M. Fischer, Why Are Insurance Contracts Subject to Special Rules of Interpretation?: Text Versus Context, 24 ARIZ. ST. L.J. 995, 996 (1992) ("The only part of the standard policy that is generally customized to the consumer-insured is the Declarations Sheet ... [T] here is little, if any, freedom to negotiate the standardized language of the insurance contract that determines the scope of coverage."); Susan Randall, Freedom of Contract in Insurance, 14 CONN. INS. L.J. 107, 125 (2008) ("'II]n some lines of insurance, all insurance companies provide identical coverage on the same take-it-or-leave-it basis."); Kent D. Syverud, The Duty to Settle, 76 VA. L. REV. 1113, 1153 (1990) (“[P]roperty owner's liability insurance contracts are standardized across insurers in a form few insureds have the power or experience to bargain around.").

${ }^{52}$ Contrary to a common misconception, flood policies sold under the National Flood Insurance Program ("NFIP") do not cover landslides. See e.g., FEMA, Standard Flood InSURANCE POLICY DWELling FORM F-122 (2015). The only arguably landslide-related coverage provided under NFIP policies is for "mudflow," which is defined as "[a] river of liquid and flowing mud on the surface of normally dry land areas, as when earth is carried by a current of water. Other earth movements, such as landslide, slope failure, or a saturated soil mass moving by liquidity down a slope, are not mudflows.” Id. § II.18. 


\section{B. The Adverse Selection, Moral Hazard and Correlated Risk Concerns That Led to the Landslide Exclusion}

Insurers provide three primary reasons for refusing to cover the risk of losses due to natural catastrophes like landslides: (1) adverse selection, (2) moral hazard, and (3) correlated risks. ${ }^{53}$

\section{Adverse Selection}

Adverse-selection theory posits that "a party facing a high risk of loss is more likely to seek insurance than a party facing a low risk." ${ }^{54}$ The theory is premised on the idea that policyholders have an informational advantage over insurers, which enables the policyholders to use that informational advantage to allow people who know they are bad risks to buy more insurance than people who are good risks. ${ }^{55}$ When an insurance policy covers only a single peril, then adverse selection is more likely to occur. ${ }^{56} \mathrm{~A}$ person who thinks his house may be damaged by a landslide because he lives on or near a hill or mountain is more likely to want to purchase landslide insurance than someone who lives on flat farmland.

The risk of adverse selection diminishes, however, if all of the most common types of risk of loss are bundled together in the same policy. For example, if homeowners policies cover all risks of loss including landslides, tornadoes, fires, vandalism, and numerous other perils, then a person who lives on or near a mountain or a hill and is concerned about landslides will not have a greater incentive to purchase the policy than a person who lives on flat farmland and is concerned about tornadoes. Thus, if the policyholder wants to or is required to have insurance to cover all losses covered under "all risk" policies, then he will buy the policy regardless of whether he thinks he needs coverage for all of the perils covered by the policy.

\section{Moral Hazard}

Moral hazard is a term that originated in insurance law to describe "the risk that an insured or insurance beneficiary would deliberately destroy the subject matter that was insured in order to obtain payment of an insurance benefit." 57 Today, the term is also used to encompass the idea that people who have insurance are less likely to take steps to avoid or minimize losses because someone

${ }^{53}$ See, e.g., Warren Kriesel \& Craig Landry, Participation in the National Flood Insurance Program: An Empirical Analysis for Coastal Properties, 71 J. Risk \& INS. 405, 405 (2004); Scales, supra note 17 , at 8-9.

${ }^{54}$ ABRAHAM \& SCHWARCZ, supra note 49, at 6; see also discussion supra note 15.

55 See Siegelman, supra note 15, at 1247.

56 See generally Robert W. KLEIn, A REgulatoR's InTRODUCTION TO THE INSURANCE INDUSTRY 10-11 (2d ed. 2005).

57 ABRAHAM \& SCHWARCZ, supra note 49 , at 7. 
else will pay the losses - in this instance, the insurer ${ }^{58}$ One commentator described moral hazard as follows: "In the broader and more usual sense in which the term is used, moral hazard means the tendency of a policyholder to be less careful in avoiding loss because she will be indemnified if the loss occurs." ${ }^{29}$

Although moral hazard is conceptually intuitive and appealing, landslides are not a peril for which moral hazard should be a serious concern. The idea that someone will not take steps to prevent his house from being bulldozed by a mudslide simply because he has insurance ignores the inability to predict when and where landslides will occur as a well as the real and significant mortal danger landslides present to people and their homes. The loss of one's home is also traumatic and inconvenient. For most people, the knowledge that their houses may be repaired or replaced does not mean they would risk their lives or be willing to become homeless simply because they have insurance.

Most people also dread the prospect of having to call and screen contractors to repair their damaged homes or to arrange for people to come to their homes to salvage their personal belongings after their home has been condemned for being unsafe. In addition, because landslides often occur quickly and with little forewarning, ${ }^{60}$ personal items of intangible and unquantifiable value - such as family heirlooms and photos - are lost in landslides. Insurance money cannot replace such items. Thus, the premise that people would not bother to take measures to avoid landslide damage if they had insurance overlooks the powerful incentives that even fully insured policyholders have to avoid or mitigate landslide disasters. ${ }^{61}$

${ }^{58}$ See discussion supra note 16.

59 JefFrey W. STEMPEL ET AL., PRINCIPLES OF InSURANCE LAW 96 (4th ed. 2011).

${ }^{60}$ Landslides \& Debris Flow, READY.GOv, https://www.ready.gov/landslides-debris-flow [https://perma.cc/HJN3-99KL] (last visited July 9, 2016).

${ }^{61}$ Homeowner's insurance policies already address moral hazard concerns through exclusions designed to exclude coverage for losses intentionally caused by the policyholder or the result of willful neglect. See Ins. SERvs. Office, InC., CAUSES of Loss - Broad Form No. CP 102006 07, at 2-5 (2007). Property policies also address moral hazard by incentivizing policyholders by requiring the policyholder to take preventative measures intended to avoid or minimize a loss and providing coverage for the costs the policyholder incurs in doing so under the "reasonable repairs" and "property protection" provisions of homeowners policies, under the "sue and labor" provisions of commercial property policies, and even under NFIP policies to a limited extent. See John S. Clark Co. v. United Nat'l Ins. Co., 304 F. Supp. 2d 758, 766-67 (M.D.N.C. 2004) ("To be covered as reimbursable sue and labor expenses [under a commercial property policy], those expenditures must be made for the benefit of the insurer in mitigating or preventing a covered loss."); SAMPLE HOMEOWNERS POLICY, AdDitional Coverages, § 2.a and Conditions, § C.4 reprinted in ABRAHAM \& SCHWARCZ, supra note 49, at 191, 199 (requiring homeowner to protect damaged property against further damage with the insurer agreeing to pay the costs incurred to do so); FEMA, STANDARD FloOd InSURANCE Policy DWELling Form F-122, at 3 (2015) (covering up to $\$ 1,000$ of the policyholder's costs incurred to avoid or minimize losses). 


\section{Correlated Risks}

Correlated risks are risks of the same type of loss by numerous people in the same geographic area at approximately the same time. ${ }^{62}$ Insurers generally attempt to avoid insuring correlated risks of loss due to actuarial and capitalization concerns; they contend they cannot accurately predict the frequency or severity of such losses or collect enough premiums to spread the risk of loss across a large enough pool of policyholders to cover the losses when they occur. ${ }^{63}$ Correlated-risk concerns are greatest when an insurer sells insurance only in a limited geographic area because the pool of policyholders is limited, and all of these policyholders are likely to face the same natural hazards at the same time. Namely, people who live in the same neighborhood have similar risks of loss for floods, earthquakes and tornadoes. Consequently, if an insurer sells policies only locally or regionally, correlated-risk concerns regarding natural disasters are well founded.

Unlike other natural disasters such as floods and earthquakes, however, the geographic scope and number of people affected by any individual landslide is limited. ${ }^{64}$ Consequently, landslides generally are not correlated risks in the traditional sense. Although some large landslides, such as the Oso Landslide that destroyed forty-nine homes and businesses,${ }^{65}$ do have some characteristics of correlated risks, landslides generally are not correlated risks. Floods and earthquakes are better examples of correlated risks because they almost simultaneously impact hundreds or thousands of people in a given geographic area ${ }^{66}$

In addition, even for traditional correlated risks, the potentially devastating financial consequences for insurers have dissipated over the past few decades as a result of the emergence of global insurance companies ${ }^{67}$ Some of these global insurers have market capitalizations of tens or hundreds of billions of dollars. ${ }^{68}$ These global insurers sell insurance to policyholders across America and throughout the world, collecting large amounts of premiums and spreading the risk of loss across enormous pools of insureds with diverse risk profiles.

Today, reinsurance and catastrophe bonds also play a larger role in further spreading an insurer's risk of loss than they did in past decades ${ }^{69}$ Consequent-

62 See discussion supra note 17.

${ }^{63}$ See Bruggeman et al., supra note 17, at 187; Cummins, supra note 17, at 342-43.

${ }^{64}$ See sources cited supra note 22.

${ }^{65}$ Supra Introduction.

${ }^{66}$ See e.g., cases cited supra note 48.

${ }^{67}$ See Yoon \& Scism, supra note 24.

68 Am. Int'l Grp., Inc. (“AIG”), for example, sells insurance in 130 countries around the world, had $\$ 68.7$ billion in revenue in 2013 , and has a market capitalization of approximately $\$ 80$ billion. See AM. INT'L GRP., INC., 2015 ANNUAL REPORT, http://www.aig.com/con tent/dam/aig/america-canada/us/documents/investor-relations/2015-annual-report.pdf [https://perma.cc/KFT8-T2CU].

${ }^{69}$ See Yoon \& Scism, supra note 24. 
ly, they too have diminished the financial impact of correlated risks on individual insurers. Reinsurance has become a worldwide business wherein global reinsurers insure all of or portions of another insurer's portfolio of business (referred to as "treaty" reinsurance).$^{70}$ Insurers also sell catastrophe bonds, which are bonds for specific types of catastrophes such as hurricanes and earthquakes, to institutional investors. ${ }^{71}$ Typically, the investors receive interest payments on the bonds and the return of their principal at the end of the bond term unless the specified catastrophe occurs, in which case the insurer keeps the principal and stops making interest payments on the bonds. ${ }^{72}$ Between 1996 and 2014, insurers issued $\$ 51$ billion in catastrophe bonds while incurring only $\$ 682$ million in losses for the catastrophes covered by the bonds (only 1.3 percent of the total amount issued) ${ }^{73}$ Thus, with the rise of global insurance companies and of global reinsurance and catastrophe bonds, the risk of a landslide loss in Puget Sound ${ }^{74}$ can now be spread to insureds located throughout the State of Washington and the world.

The problem of correlated risks is also much greater when perils are insured separately, as opposed to when coverage for numerous perils are bundled together under the same policy. If insurance for landslides is sold only as standalone named-peril insurance, then the risk that the pool of insureds will suffer landslide losses at the same time would be more correlated because people in the same high risk areas would be the ones most likely to purchase landslide insurance. If the policies being sold bundled coverage for landslides together with other common perils such as tornadoes, fire and theft, then the pool of policyholders who would purchase such insurance would be much more diverse from both geographic and risk profile perspectives. Consequently, although the correlation of the risk of landslide losses in any given geographic area would not change, the risk that the entire pool of insureds would suffer landslide losses would not be correlated.

Consider again the example of two policyholders: one who lives on a mountain with landslide concerns, and the other who lives on flat farmland with tornado concerns. Because coverage for the perils of tornadoes and landslides would be bundled together under the same policy, the risk of a landslide loss for the two policyholders would not be correlated. Nor would the risk of wind damage for the two policyholders be correlated. Thus, bundling together coverage for multiple perils into a single policy not only reduces or eliminates adverse-selection concerns, but it also decreases correlated risk concerns be-

70 Am. INT'L GRP., INC., supra note 68, at 186, 282.

${ }^{71}$ See Scales, supra note 17, at 46; Yoon \& Scism, supra note 24.

72 Scales, supra note 17 , at 46.

${ }^{73}$ Yoon \& Scism, supra note 24.

${ }^{74}$ See generally Seattle, WA Landslide Information, U.S. GEOLOGICAL SURVEY - LANDSLIDE HAZARDS PROGRAM, http://landslides.usgs.gov/state_local/seattle.php [https://perma.cc/6BM 8-6BRC] (last visited July 10, 2016). 
cause the larger pool of insureds who might purchase such policies likely would have more diverse risk profiles.

\section{Courts' Inconsistent Applications of the Landslide Exclusion}

Despite the broad language of the landslide exclusion that is contained in "all risk" property policies, ${ }^{75}$ homeowners and business owners often mistakenly believe they are covered for landslide losses. In some jurisdictions, this belief is reinforced by courts' inconsistent interpretations of the landslide exclusion.

Because "all risk" homeowners policies are contracts of adhesion that are sold on a take-it-or-leave-it basis and contain numerous exclusions,$^{76}$ courts in some jurisdictions have interpreted an older version of the landslide exclusion very narrowly to encompass only naturally occurring landslides. ${ }^{77}$ This is because the "earth movement" exclusion that encompasses landslides was created to address unpredictable, widespread natural catastrophes such as earthquakes, as opposed to man-made events that impact only a single or a few policyholders at a time. ${ }^{78}$ Other courts have declined to apply the exclusion at times when the landslide results from multiple causes and the efficient proximate cause of the landslide is a covered peril. ${ }^{79}$ In reaching such decisions, the courts have applied well-established rules of policy interpretation that dictate that exclu-

75 See InS. SERvs. OfFICE, InC., supra note 50.

${ }^{76}$ Randall, supra note 51.

77 See, e.g., Sentinel Assocs. v. Am. Mfrs. Mut. Ins. Co., 804 F. Supp. 815, 819 (E.D. Va. 1992), aff'd, 30 F.3d 130 (4th Cir. 1994); Opsal v. United Servs. Auto. Ass'n, 10 Cal. Rptr. 2d 352, 355 (Cal. Ct. App. 1991); Steele v. Statesman Ins. Co., 607 A.2d 742, 743 (Pa. 1992); Murray v. State Farm Fire \& Cas. Co., 509 S.E.2d 1, 9, n.6 (W. Va. 1998); Robert P. Dahlquist, Perspectives on Subsidence Exclusions and the Role of Concurrent Causation in Earth Movement Cases, 37 TORT \& INS. L.J. 949, 960-62 (2002); Risley, supra note 10, at 1153-59. As reflected in Part II.A, insurers have responded to such decisions by adding policy language to specify that they also intend to exclude coverage for landslides caused by human activities.

${ }^{78}$ See supra note 48.

79 See, e.g., CAL. INS. CODE $\S 530$ (West 2016) (“An insurer is liable for a loss of which a peril insured against was the proximate cause, although a peril not contemplated by the contract may have been a remote cause of the loss; but he is not liable for a loss of which the peril insured against was only a remote cause."); Garvey v. State Farm Fire \& Cas. Co., 770 P.2d 704, 715 (Cal. 1989) (stating "efficient proximate cause" analysis should be conducted to determine whether the earth movement exclusion applies if a covered peril was also involved in causing the loss); Safeco Ins. Co. v. Hirschmann, 773 P.2d 413 (Wash. 1989) (explaining insurers cannot circumvent the "efficient proximate cause" rule by drafting exclusions that would allow a remote cause of loss encompassed by the earth movement to preclude coverage where the proximate cause of the damage was a covered peril); Murray, 509 S.E.2d at 10 (stating insurers cannot circumvent the "efficient proximate cause" doctrine through policy language and concluding the earth movement clause is ambiguous as to whether it applies only to losses resulting from natural, rather than man-made, forces); Dahlquist, supra note 77, at 963-69; Risley, supra note 10, at 1155-56. 
sions should be interpreted narrowly, and any ambiguities in the policy language should be interpreted in favor of coverage. ${ }^{80}$

In other jurisdictions, however, the courts have concluded that the "earth movement" exclusion unambiguously excludes coverage for the landslide loss at issue. ${ }^{81}$ Thus, although the "earth movement" exclusion expressly purports to exclude coverage for landslide losses, whether a homeowner policy will actually cover a landslide loss depends upon: (1) the law of the jurisdiction where the loss occurs; (2) the precise wording of the landslide exclusion at issue; and (3) the cause(s) of the landslide. ${ }^{82}$ This uncertainty regarding the applicability of the exclusion undermines one of the principal purposes of contracts-ensuring that the parties' rights and obligations are memorialized in a way that allows the parties to understand and predict their future obligations. ${ }^{83}$

\section{The Limited Availability of Coverage for Landslides Under Stand-Alone}

${ }^{80}$ See, e.g., Tews Funeral Home, Inc. v. Ohio Cas. Ins. Co., 832 F.2d 1037, 1045 (7th Cir. 1987) (holding policy excluding acts explicitly covered in prior section of policy construed against insurer); Titan Indem. Co. v. Newton, 39 F. Supp. 2d 1336, 1348 (N.D. Ala. 1999) (finding coverage even though "[t]he limitations of [the] policy completely swallow up the insuring provisions"); Crane v. State Farm Fire \& Cas. Co., 485 P.2d 1129, 1130 (Cal. 1971) ("Any ambiguity or uncertainty in an insurance policy is to be resolved against the insurer.”); Phillips Home Builders, Inc. v. Travelers Ins. Co., 700 A.2d 127, 129 (Del. 1997) ("If there is an ambiguity, however, the contract language is "construed most strongly against the insurance company that drafted it.' "); RPM Pizza, Inc. v. Auto. Cas. Ins. Co., 601 So. 2d 1366, 1369 (La. 1992) (“"A]ny ambiguity must be construed against the insurance company and in favor of the reasonable construction that affords coverage."); Bailer v. Erie Ins. Exch., 687 A.2d 1375, 1380 (Md. 1997) (finding "[i]f the exclusion totally swallows the insuring provision," then such provisions create the greatest form of ambiguity, and the insurer is obliged to provide coverage); Am. Bumper \& Mfg. Co. v. Hartford Fire Ins. Co., 550 N.W.2d 475, 480 (Mich. 1996) ("[I]n construing insurance contracts, any ambiguities are strictly construed against the insurer to maximize coverage.”); Gomolka v. State Auto. Mut. Ins. Co., 436 N.E.2d 1347, 1348-49 (Ohio 1982) (quoting Butche v. Ohio Cas. Ins. Co., 187 N.E.2d 20, 22 (1962)) ("Policies of insurance, which are in language selected by the insurer and which are reasonably open to different interpretations, will be construed most favorably for the insured.").

${ }^{81}$ See, e.g., Stankova v. Metro. Prop. \& Cas. Ins. Co., No. CIV. 12-8016-PCT-PGR, 2012 WL 5032564, at*4 (D. Ariz. Oct. 18, 2012); York v. Liberty Mut. Grp., Inc., No. 09-113HA, 2010 WL 275653, at*4 (D. Or. Jan. 15, 2010); Olmstead v. Lumbermens Mut. Ins. Co., 259 N.E.2d 123, 127 (Ohio 1970).

${ }^{82}$ See supra notes 77-81.

${ }^{83}$ See, e.g., Michael Hunter Schwartz \& Denise Riebe, Contracts: A Context And PRACTICE CASEBOOK 5 (2009) ("[P]redictability promotes our free market economy by providing certainty for those involved in exchanging goods and services. If a merchant knows the legal consequences of her negotiating efforts or of the language she selects for her contracts, she can act accordingly. This predictability encourages people to enter into contracts, secure in the knowledge that those contracts will be enforced."); Eric A. Posner, A Theory of Contract Law Under Conditions of Radical Judicial Error, 94 Nw. U. L. REv. 749, 751 (2000) ("Long-term contracts raise a straightforward, but seemingly intractable problem: in the long term events are so hard to predict, that parties will not be able to allocate future obligations and payments in a way that maximizes the value of their contract."). 
Surplus Policies

In some states, coverage for landslides is available under stand-alone, named-peril landslide insurance policies, known as "difference-in-conditions" policies,${ }^{84}$ which are sold by "surplus" line insurers.$^{85}$ Landslide insurance can be purchased as a stand-alone coverage in states such as California, ${ }^{86}$ Oregon, Utah, and Washington. ${ }^{87}$ Because it is sold as a surplus-line policy primarily by Lloyd's of London, however, many insurance agents are not even aware of its existence. $^{88}$

The cost for such insurance, which often covers only the damage to the contents of the house and not damage to the land (and sometimes not even the house itself), is high-approximately $\$ 1,000$ a year for a $\$ 300,000$ house with a

${ }^{84}$ See, e.g., Bronson, supra note 9; Graham Johnson, Standard Homeowners Insurance Doesn't Cover Landslides, KIRO 7 (Mar. 26, 2014, 8:10 PM), http://www.kiro tv.com/news/news/standard-homeowners-insurance-doesnt-cover-landsli/nfMCq/ [https://per ma.cc/69QB-56PC]; Kyle Stokes, Are You Covered? Few Washington Homeowners Hold Insurance for Landslides, KPLU 88.5 (Mar. 25, 2014), http://www.kplu.org/post/are-youcovered-few-washington-homeowners-hold-insurance-landslides [https://perma.cc/56Q3-5W G5].

${ }^{85}$ See, e.g., Kenneth S. Abraham, Insurance Law And Regulation 780 (5th ed. 2010) (" "S S ] urplus line insurers ... are not licensed, and are permitted to do business in the state only when a prospective purchaser is unable to obtain coverage from an insurer in the admitted market.").

${ }^{86}$ Notably, under earthquake policies sold by the California Earthquake Authority, landslide losses are expressly excluded from coverage unless the landslide was caused by an earthquake. See Cal. EarthQuake Auth., Basic EarthquaKe Policy-Homeowners $\S 5$, at 13 (2012). Consequently, in California a homeowner needs to purchase separate policies to cover landslide losses and earthquake losses in addition to purchasing a homeowners policy.

${ }^{87}$ Bronson, supra note 9; Landslide, Flood and Earthquake Available to Utahns, DAILY HerAld (Provo) (Aug. 6, 2008), http://www.heraldextra.com/news/local/landslide-floodand-earthquake-available-to-utahns/article_37d6a86b-1517-59f7-8121-b04bbd2640a7.html [https://perma.cc/D6Q7-M8FY]; Diane Wedner, Landslide Policy: Buy or Bypass?, L.A. TiMES (June 12, 2005), http://articles.latimes.com/2005/jun/12/realestate/re-landslide12 [https://perma.cc/X7R8-8PUQ]; "Snapp.com" Summary, SNAPP \& SON INS., http://in surancearchieve.org/site/snapp.com/landslide+insurance [https://perma.cc/XU55-7R6V] (last visited July 10, 2016). An internet-based service owned and operated by a wholesale insurance broker, Poultan Associates, Inc., known as the National Catastrophe Insurance Program ("NCIP") sells stand-alone policies underwritten by Lloyd's of London. According to the NCIP website, the policies cover earthquakes, landslides and floods. Frequently Asked Questions, CATCOVERAGE.COM, https://www.catcoverage.com/faq.aspx [https://perma.cc/J3F8ANBH] (follow "FAQ" hyperlink; select "About Us" tab) (last visited July 10, 2016). The sale of the policies and payment of premiums is all done through the internet. Id. The website does not address the claims submission or payment process. Id. The policies can be purchased for qualifying properties in most states. Frequently Asked Questions, CATCOVERAGE.COM, https://www.catcoverage.com/faq.aspx [https://perma.cc/J3F8-ANBH] (follow "FAQ" hyperlink; select "In which states can I get coverage?" tab) (last visited July 10, 2016).

${ }^{88}$ See, e.g., Goldberg, supra note 37, at 124; Bronson, supra note 9. 
deductible of 5 percent to 20 percent of the value of the property. ${ }^{89}$ Landslide policies also often exclude coverage for landslides caused by earthquakes ${ }^{90}$ If a landslide previously has occurred in the area, then the homeowner will likely not be able to purchase landslide insurance to cover future landslide losses. ${ }^{91}$ And, according to the Washington State Office of the Insurance Commissioner, if a house is located in a high risk area such as on "a hillside, coverage may be difficult to obtain." ${ }^{92}$ Consequently, only about 4,700 , or approximately 1 percent of homes and businesses in the State of Washington have stand-alone landslide insurance due to high cost, lack of availability, and lack of information regarding where to purchase it. ${ }^{93}$ Indeed, because so few landslide policies have been sold, there are no reported decisions arising from disputes between a policyholder and an insurer under a stand-alone landslide policy.

In other places where landslides are also prevalent such as in Pittsburgh, Pennsylvania, even high-priced, stand-alone landslide policies are not available for purchase..$^{44}$ Thus, despite being in one of the areas in the country with the highest risk for landslides, property owners in Pittsburgh, like homeowners in most parts of the country, are uninsured for naturally occurring landslide losses. ${ }^{95}$

89 See, e.g., Goldberg, supra note 37, at 124; Bhatt, supra note 40; Bronson, supra note 9; Stokes, supra note 84; Wedner, supra note 87.

90 See Goldberg, supra note 37, at 124.

${ }^{91}$ Bhatt, supra note 40 (According to Sandi Esparza, a manager for the insurance broker Hub International Northwest, "If you live in an area known to have a high potential for landslides, you probably can't get the insurance ... [y] ou need to buy it before your area erodes and you need it[.]").

${ }^{92}$ Landslide Insurance, WASH. STATE OFFICE OF THE INS. COMM'R, http://www.in surance.wa.gov/your-insurance/home-insurance/landslides/ [https://perma.cc/CJQ6-HRKM] (last visited June 17, 2014).

93 See, e.g., Bronson, supra note 9; Johnson, supra note 40.

94 In 2009, the Pennsylvania House of Representatives passed a bill that created a statesponsored insurance program to cover landslide losses. See H.R. 523, 2009 Gen. Assemb., Reg. Sess. (Pa. 2009). In sponsoring the bill, Representative Tony DeLuca noted that, "many people in western Pennsylvania have lost their homes to landslides because they did not have an opportunity to purchase insurance to protect their homes." Pennsylvania House Approves Landslide Insurance Program, InS. \& FIN. ADVISOR (Oct. 19, 2009), http://ifawebnews.com/2009/10/19/pennsylvania-house-approves-landslide-insurance-progra $\mathrm{m} /$ [https://perma.cc/88WN-X96L]. In 2011, however, without a public explanation, the bill died in committee in Pennsylvania's state senate. S.B. 597, 2011 Gen. Assemb., Reg. Sess. (Pa. 2011).

${ }^{95}$ In Steele v. Statesman Ins. Co., 607 A.2d 742, 743 (Pa. 1992), the Pennsylvania Supreme Court held that an "earth movement" exclusion only applied to naturally occurring landslides. The court has not yet considered, however, the newer language in the landslide exclusion quoted in Part II.A that purports to also exclude coverage for landslides caused by human activities. And, of course, most landslides in Western Pennsylvania are naturally occurring so the Steele decision may be of limited value to homeowners today in Pennsylvania. 


\section{Potential Solutions to the LANDSLIDE INSURANCE PROBLEM}

The combination of the landslide exclusion in "all risk" homeowners and commercial-property policies and the limited availability of high-cost, standalone policies has created a $\$ 3.5$ billion uninsured landslide loss problem in America. ${ }^{96}$ This Part of the Article explains the need for more comprehensive landslide insurance coverage in America and then offers two potential solutions: homeowners insurance and state-sponsored landslide insurance programs.

\section{A. The Necessity of Insurance}

Insurance plays a socially and financially critical role in developed countries such as the United States. Insurance has even been described as a "social instrument" because of the important role it plays in protecting the limited assets of individuals by transferring the risk of losses from individuals who cannot financially afford to absorb the losses to a larger population through an insurer intermediary. ${ }^{97}$ Indeed, over two hundred years ago when this country was originally founded, people and businesses recognized the importance of insurance as a social safety net, as evidenced by their paying premiums to a "mutual" company or group to create a pool of money from which losses were paid.$^{98}$ Essentially, the insurance company operated as a third-party administrator that: (1) collected the premiums in order to create the pool of money from which losses could be paid; and (2) subsequently paid the losses of the members of the group as such losses were incurred. ${ }^{99}$

Homeowners insurance is even more important today than it was when the United States was first founded. Indeed, due to lending requirements, without homeowners insurance, homeownership is not even possible for most people. ${ }^{100}$

96 U.S. GeOlOGICAL SURVEY, supra note 10.

97 See, e.g., Jeffrey W. Stempel, The Insurance Policy as Social Instrument and Social Institution, 51 WM. \& MARY L. REV. 1489, 1489 (2010); Deborah A. Stone, Beyond Moral Hazard: Insurance as Moral Opportunity, 6 ConN. INS. L.J. 11, 26-29 (1999) ("Because virtually every adult citizen participates in various forms of mandatory insurance, from automobile liability insurance to unemployment insurance, old-age pensions and disability insurance, everyone is exposed to two of the moral assumptions of these programs: collective responsibility for the well-being of individuals and individual responsibility for the well-being of others.").

98 See Jay M. Feinman, Delay, Deny, Defend: Why Insurance Companies Don't Pay Claims AND WHAT You CAN Do ABOUT It 21 (2010); JERRY \& RichMOND, supra note 16, at 18; Christopher C. French, The Role of the Profit Imperative in Risk Management, 17 U. PA. J. Bus. L. 1081, 1084-86 (2015) (arguing that the social purpose of insurance is being marginalized by private insurers' pursuit of profits).

99 See FEINMAN, supra note 98, at 22-23; JERRY \& RICHMOND, supra note 16, at 47-48 (noting that mutual companies are not designed for profit, but instead to provide insurance to the members of the company).

${ }^{100}$ See CONSUMER Fin. Prot. Bureau, supra note 20. 
Anyone who needs to borrow money from a bank to purchase a house must purchase homeowners insurance because banks require such insurance as a prerequisite to issuing a mortgage. ${ }^{101}$

As for-profit, publicly traded stock companies have come to dominate the insurance industry since the $1990 \mathrm{~s},{ }^{102}$ insurers have attempted to improve their profitability by decreasing the coverage that is provided under insurance policies through the addition of numerous exclusions for some of the most common risks that property owners face. ${ }^{103}$ That trend should be reversed, and the exclusion for landslide losses would be a great place to start. Homeowners insurance, as a social necessity today, should be required to cover losses caused by landslides. Indeed, catastrophic risks such as landslides are exactly the types of risk of loss that an "all risk" homeowners policy should cover. If people, businesses, and communities are not covered by property insurance for the very types of losses that have the most devastating impacts on them, then the risktransferring and social safety net purposes of insurance cannot be fulfilled. ${ }^{104}$

\section{B. State Action to Remove the Landslide Exclusion from Policies}

As discussed in Part II, the historical reasons for excluding coverage for landslides under "all risk" homeowners policies - adverse selection, moral hazard and correlated risks - are not valid. Consequently, states or the federal government should mandate that the landslide exclusion in homeowners policies be eliminated. ${ }^{105}$

Albeit in an ad hoc manner, some state and federal legislatures have already begun attempting to force the insurance industry to fulfill the risktransferring and social safety net purposes of insurance by requiring insurers to provide products that cover some of the most common and devastating losses

101 See Martin F. Grace et al., Catastrophe Insurance: Consumer Demand, Markets AND REgUlATION 83 (2003) (discussing the demand for homeowners insurance, stating that "homeowners insurance ... is essentially mandatory"); Stempel, supra note 97, at 1497.

102 See Otgontsetseg Erhemjamts \& J. Tyler Leverty, The Demise of the Mutual Organizational Form: An Investigation of the Life Insurance Industry, 42 J. MONEY, CREDIT \& BANKING 1011, 1011-12 (2010); French, supra note 98, at 1093.

${ }^{103}$ See French, supra note 98, at 1084-85.

$104 \mathrm{Id}$. at 1084.

${ }^{105}$ If homeowners' insurance covered landslides, then another added benefit would be much less litigation following landslide events. As things currently stand, policyholders and their insurers spend countless dollars engaged in litigation whenever landslides occur. As discussed in Part II.C, when faced with a potentially uninsured catastrophic loss of their homes, policyholders often sue and then, in some states such as California and Washington, strain to find a covered cause of the loss that may have played a role in causing the landslide to escape the landslide exclusion. And, because some courts are sympathetic to these concurrent causation arguments, policyholders are incentivized to sue. See cases cited supra note 80. If the landslide exclusion were eliminated, then such litigation also would be eliminated. 
that Americans face. ${ }^{106}$ For health insurance, as an example, the Affordable Care Act prohibits insurers from: (1) refusing to insure certain people; (2) cancelling insurance for people who become sick; and (3) using reverse adverse selection to charge people who fall under certain risk classifications prohibitively expensive premiums. ${ }^{107}$

In the area of auto insurance, some state legislatures have enacted statutes that eliminate certain policy exclusions or that require insurers to cover drivers whom insurers would refuse to cover if they were not statutorily required to do so. ${ }^{108}$ For example, drivers whom insurers refuse to insure because insurers do not consider them adequately profitable due to their risk profiles can still get a minimum amount of liability coverage in most states through assigned risk insurance pools. ${ }^{109}$

In the property insurance context, many states have passed statutes that nullify the "innocent co-insured" exclusion. ${ }^{110}$ This exclusion prevents innocent co-insureds from recovering under policies for losses that were intentionally caused by another insured, such as when one spouse who is no longer living in the couple's house destroys the house in order to prevent the spouse from having it. ${ }^{111}$ By statutorily eliminating the exclusion, the innocent spouse can still recover under the policy.

In sum, states and the federal government have the power, and they exercise that power, to force insurers to cover risks the insurers would not voluntarily choose to cover when the consequences of not ensuring the risk are understood to be sufficiently important. Insuring landslides is another example of where states or the federal government should exercise their regulatory power over the insurance industry to require insurers to cover such losses under "all risk" homeowners insurance.

\section{State-Sponsored Landslide Insurance Programs}

If there are lingering concerns that insurer insolvencies would occur if insurers were required to cover landslides notwithstanding the risk-reducing and risk-spreading mechanisms discussed in Part II.B.3, then states or the federal government could act as reinsurers for landslide losses that exceed a certain stated amount for any insurer. The United States federal government currently

106 InT'L Monetary Fund, Financial Sector Assessment Program Detailed Assessment of Observance on Insurance Core Principles, Country Report U.S. No. 15/90, at 21 (2015), https://www.treasury.gov/resource-center/international/Documents/cr1590.pdf [https://perm a.cc/LY8C-MFD5].

107 See generally ABRAHAM \& SCHWARCZ, supra note 49, at 354-55.

108 See, e.g., id. at 656-58.

109 See, e.g., ABRAHAM, supra note 85, at 771.

110 See, e.g., JERRY \& RICHMOND, supra note 16, at 425-26.

111 See, e.g., id. at 423-26. 
acts as the reinsurer for terrorism losses. ${ }^{112}$ It could do so for landslide losses as well if global reinsurers were to refuse to sell reinsurance treaties to insurers that cover landslide losses in America.

If "all risk" homeowners insurance were required to cover landslide losses, it is also conceivable that some private insurers would refuse to sell homeowners insurance because they might conclude that such insurance would no longer be adequately profitable. ${ }^{113}$ If that unlikely scenario occurred and the currently robust market for homeowners insurance disappeared, then state-sponsored insurance programs could be created to fill the void.

It could be argued that, under current law, state-sponsored insurance programs are better suited than private insurers to insure certain types of natural catastrophes in America for a number of reasons. First, tax laws effectively discourage private insurers from accumulating capital to pay future losses because the income generated by insurers that could be set aside to pay future losses is taxed. ${ }^{114}$ Then, if that income is not distributed to shareholders, the income generated by the money (which could be used to pay future unrealized losses) is also taxed. ${ }^{115}$ Second, companies with accumulated surplus capital, which an insurer must have in order to cover the losses associated with natural catastrophes, are takeover targets for corporate raiders. ${ }^{116}$ Idle capital is something that corporate raiders generally believe can be redeployed for better uses. ${ }^{117}$ Third, insurers are not permitted under the current accounting rules to create reserves for the payment of future claims if the events giving rise to the losses and claims have not yet occurred. ${ }^{118}$ Thus, collectively these laws incentivize stock insurance companies to pay surplus earnings to shareholders in the form of div-

112 See Terrorism Risk Insurance Act of 2002, Pub. L. No. 107-297, § 110, 116 Stat. 2322 (2002) (codified as amended in scattered sections of 15 U.S.C.); Michelle E. Boardman, Known Unknowns: The Illusion of Terrorism Insurance, 93 GEO. L.J. 783, 788-89 (2005).

${ }_{113}$ Also, despite the availability of reinsurance and catastrophe bonds, smaller insurers (particularly mutual companies) may not be adequately capitalized to cover natural catastrophes such as landslides. Unlike publicly traded stock companies, which can issue new shares, mutual companies' primary way of raising capital is by retaining surplus. See, e.g., Erhemjamts \& Leverty, supra note 102, at 1011; Henry Hansmann, The Organization of Insurance Companies: Mutual versus Stock, 1 J. L. ECON. \& ORG. 125, 138 (1985); Dwight M. Jaffee \& Thomas Russell, Catastrophe Insurance, Capital Markets, and Uninsurable Risks, 64 J. RISK \& INS. 205, 216-17 (1997); James A. Smallenberger, Restructuring Mutual Life Insurance Companies: A Practical Guide Through the Process, 49 DrAKE L. REV. 513, 518-19 (2001). Thus, in the absence of reinsurance and catastrophe bonds, small stock companies and mutual companies may not be well suited to insure catastrophic risks such as landslides.

114 See Cummins, supra note 17, at 371; Jaffee \& Russell, supra note 113, at 212, 222.

115 See Jaffee \& Russell, supra note 113, at 212.

116 See id. at 213.

117 Id.

118 See Cummins, supra note 17, at 371-72; Jaffee \& Russell, supra note 113, at 209, 222 (discussing Financial Accounting Standards Board ("FASB") Statement No. 5 Accounting for Contingencies, which precludes an insurance company from earmarking capital surplus to pay for future catastrophic losses that have not yet occurred). 
idends or stock repurchases so many insurers are not be adequately capitalized to cover natural catastrophes. ${ }^{119}$

State-sponsored insurance programs, on the other hand, would not be subject to these laws so they would be well positioned to insure natural catastrophes. State-sponsored insurance programs would not be subject to shareholders' demanding returns on their investments in the form of dividends or stock repurchases. Also, state-sponsored insurance programs would not be subject to the tax and accounting rules that discourage private companies from accumulating capital. Further, state-sponsored insurance programs would not be takeover targets for corporate raiders because such programs would not, of course, be available for purchase. Consequently, state-sponsored insurance programs could accumulate the capital needed to pay claims for large catastrophic losses caused by disasters without the need to distribute such capital to shareholders. In short, many of the legal impediments that private insurers currently must overcome in order to cover natural catastrophic risks such as landslides would not apply to state-sponsored insurance programs.

Another potential advantage of state-sponsored insurance programs might be lower premiums than the rates currently charged by the few insurers that sell stand-alone landslide policies. Because private insurers aggressively compete for business in many lines of insurance such as homeowners insurance, a significant portion of the premiums they collect is paid to insurance agents as sales commissions. ${ }^{120}$ Indeed, some reports indicate that as much as 20 percent of the premiums collected are paid to insurance agents as sales commissions. ${ }^{121}$ There would be no need to pay sales commissions to employees of a state-sponsored landslide insurance program because the program's purpose would not be to make as much profit as possible for shareholders.

Private insurers also currently spend significant amounts of money (generated by the premiums they collect) on advertising. ${ }^{122}$ Who has not seen the television commercials in which All State features a beat up guy - "Mayhem"damaging peoples' homes and vehicles while a deep voice counsels viewers to buy Allstate Insurance. ${ }^{123}$ Such TV ads and other marketing efforts cost the fifty largest insurers approximately $\$ 2.5$ billion annually; ${ }^{124}$ these costs naturally are passed on to customers in the form of higher premiums. These expenses could be avoided by a state-sponsored landslide insurance program.

119 See Jaffee \& Russell, supra note 113, at 212.

${ }^{120}$ See Thomas von Ungern-Sternberg, The Benefits of Introducing a Mandatory State Hurricane Insurance Scheme in Florida 10 (Oct. 2009) (Working Papers in Econ.); see also Cassandra R. Cole et al., The Use of Postloss Financing of Catastrophic Risk, 14 Risk MGMT. \& INS. REV. 265, 271 (2011).

${ }^{121}$ See von Ungern-Sternberg, supra note 120, at 10.

122 See id. at 11.

${ }^{123}$ Mayhem is Everywhere, ALLSTATE, http://www.allstateonline.com/lp/mayhem [https:// perma.cc/VUW3-N7XJ] (last visited July 13, 2016).

${ }^{124}$ See FEINMAN, supra note 98 , at 54. 
After a person applies for insurance, insurers then spend significant amounts of money (again generated by the premiums they collect) during the underwriting process in an attempt to identify and eliminate the high-risk people who are most likely to make claims - the "bad risks." ${ }^{25}$ On the other hand, if state-sponsored programs accepted all of the 96 percent of homeowners who buy homeowners insurance, ${ }^{126}$ very little money would need to be spent on underwriting efforts directed toward eliminating the highest risk policyholders from the pool of insureds because the full range of risk profiles, from high to low, would be included in the insurance pool.

Theoretically, state-sponsored insurance programs also could result in reduced premium rates because such programs would not need to spend as much money investigating and litigating their policyholders' claims, as the profit imperative currently mandates that private insurers do in order to maximize profits for shareholders. ${ }^{127}$ Currently, insurers spend approximately 12 percent of their premium revenues investigating and litigating claims. ${ }^{128}$ Because there are no significant negative financial consequences for disputing claims, litigating claims makes good business sense for publicly traded insurance companies under existing laws because every dollar (above and beyond their litigation costs) that insurers can avoid paying on claims increases insurers' profitability. ${ }^{129}$ To the contrary, unless the policyholder can prove an insurer acted in bad faith, which is very difficult to do under current insurance law, ${ }^{130}$ an insurer that wrongfully denies its policyholder's claim, delays payment of the claim, or underpays the claim is liable only for the amount it should have paid plus a nomi-

125 See Bruggeman et al., supra note 17, at 217; Cole et al., supra note 120, at 271; von Ungern-Sternberg, supra note 120, at 13.

${ }^{126}$ See INS. INFO. INST., supra note 19.

127 See Jaffee \& Russell, supra note 113, at 213.

128 See von Ungern-Sternberg, supra note 120, at 11.

129 See FeInMAN, supra note 98, at 2, 5. Insurers' aggressive claims investigation and payment practices do not hurt their bottom lines in the form of lost customers caused by gaining a reputation for unfair claims payment practices because the information regarding insurers claims payment practices is not disclosed to the public. Id. at 39-40.

${ }^{130}$ The standards for proving bad faith vary widely in jurisdictions throughout America. Some jurisdictions require that the policyholder prove that the insurer acted egregiously or with a dishonest intent, while others require the policyholder to prove that the insurer acted "unreasonably" with respect to the handling or payment of a claim and that the insurer knew or had reason to know that its behavior was unreasonable. See, e.g., JERRY \& RICHMOND, supra note 16, at 165-70 (explaining how the determination of bad faith often centers around the unreasonableness of the insurer's conduct but varies across jurisdictions); Douglas R. Richmond, An Overview of Insurance Bad Faith Law and Litigation, 25 SETON Hall L. REV. 74, 96-103 (1994) (discussing what constitutes bad faith and looking at various standards set forth by the courts). Many jurisdictions require that the insurer's bad faith conduct be proven by the policyholder with "clear and convincing evidence." See, e.g., JERRY \& RICHMOND, supra note 16, at 167 (explaining how some courts require the plaintiff to provide proof of bad faith by "clear and convincing evidence"). 
nal interest award in today's low interest rate environment. ${ }^{131}$ Thus, insurers are legally incentivized to: (1) pay as little as possible on claims regardless of the merits of the claims and (2) avoid paying claims for as long as possible because there are almost no legal consequences for doing so and insurers make a lot of money by holding and investing the money that is used to pay claims (known as the "float" in the insurance industry). ${ }^{132}$ That would not be the case for a state-sponsored landslide insurance program because it would not be governed by the profit imperative; instead, it would need only to verify the validity of a claim before paying it.

Ideally, a state-sponsored program covering landslides would sell "all risk" policies that bundle the coverage for multiple perils together under a single policy. If state-sponsored property insurance programs covered only the peril of landslides, then adverse selection would be a concern. Only the people most likely to suffer landslides would purchase landslide policies. Consequently, because the pool of insureds would be relatively small, the premiums for such insurance necessarily would need to be high for the program to be actuarially sound.

As discussed in Part II.D, high premiums are one of the problems with the landslide insurance currently sold by international surplus insurers. To make stand-alone landslide insurance affordable for most homeowners under statesponsored programs, such programs likely would need to subsidize the premium rates. If actuarially sound premiums were not charged, however, then statesponsored landslide insurance programs could become insolvent like the federal National Flood Insurance Program ("NFIP") (a program that sells standalone policies to cover flood losses at subsidized rates largely because actuarially sound premium rates are not affordable for many homeowners). ${ }^{133}$ Thus,

131 See, e.g., JERRY \& RICHMOND, supra note 16, at 161 (explaining that bad faith remedies were created due to the "apparent inadequacy of contract remedies to compensate insureds and deter insurers from elevating their own interests above their insureds"). In order to actually be awarded a penalty such as punitive damages; however, in many jurisdictions the policyholder must prove by clear and convincing evidence that the insurer engaged in egregious, wanton misconduct. Id. at 167, 169.

132 See, e.g., MARK R. GREENE, Risk AND InSURANCE 147 (4th ed. 1977) (“In property and liability insurance, investment income has accounted for a very substantial portion of total profits and has served to offset frequent underwriting losses.”); Eliot Martin Blake, Comment, Rumors of Crisis: Considering the Insurance Crisis and Tort Reform in an Information Vacuum, 37 EMORY L.J. 401, 422-23 (1988) ("Insurers do not simply hang onto premiums, of course; they invest them for the time period between payment of premiums and payment of losses.... The role of investment income in the [insurance] industry is particularly important. Studies have concluded that investment income allows the industry to remain profitable as a whole even with significant negative underwriting losses."); see also FEINMAN, supra note 98, at 16; French, supra note 98, at 1120; Jeffrey W. Stempel, Assessing the Coverage Carnage: Asbestos Liability and Insurance After Three Decades of Dispute, 12 ConN. Ins. L.J. 349, 357 n.18 (2006).

${ }^{133}$ See, e.g., Moving Ahead for Progress in the 21st Century Act, Pub. L. No. 112-141, $\S 100248,126$ Stat. 405, 969 (2012) (amending 42 U.S.C. $§ 4001$ et. seq.); see also Scales, 
although state-sponsored landslide insurance programs would have many advantages over private insurance, if the coverage were sold as stand-alone policies, then such programs could suffer from many of the same problems as the NFIP, such as insolvency and low participation rates. ${ }^{134}$

\section{Insurance for Landslide Losses in other Countries}

In considering whether it is feasible for landslides to be covered under "all risk" homeowners policies or state-sponsored programs, one can look to the ways in which other countries handle insurance for landslides. In numerous countries, landslide losses are mandatorily covered by private homeowners insurance, by a state-sponsored program, or by a combination of the two. ${ }^{135} \mathrm{New}$ Zealand, France, Belgium, Norway, Romania, Switzerland, Iceland, and Australia are eight examples to consider.

In New Zealand, a government-sponsored insurance program covers landslide losses, along with other natural catastrophes. ${ }^{136}$ The insurance covers both land and structural damage. ${ }^{137}$ The premiums are not actuarially calculated. ${ }^{138}$ Instead, the premium is based upon a percentage of the insured's fire insurance premium regardless of the insured's risk of a landslide loss because it is con-

supra note 17, at 16; U.S. Gov'T ACCOUnTABILITy OfFice, GAO-14-364T, ExTREME WEATHER EVENTS - Limiting FEDERAL FisCAL EXPOSURE AND INCREASING THE NATiON's RESILIENCE 3 (2014) (statement of Mark Gaffigan, Managing Dir. Nat'l Res. and Env't). See generally Homeowner Flood Insurance Affordability Act of 2014, Pub. L. No. 113-89, § 2, 128 Stat. 1020 (codified as amended at 42 U.S.C. § 4014).

${ }^{134}$ See French, supra note 14, at 68-71; see also U.S. Gov'T ACCOUNTABILITY OfFICE, GAO-14-127, FlOOD InSURANCE: StRATEgIES FOR INCREASING PRIVATE SECTOR INVOLVEMENT 2 (2014) (currently there are only 5.5 million NFIP policyholders); Rachel Lisotta, In Over Our Heads: The Inefficiencies of the National Flood Insurance Program and the Institution of Federal Tax Incentives, 10 LOY. MAR. L.J. 511, 518 (2012) (“[A] study in 2005 indicated 84 percent of residents in flood-prone areas had not purchased flood insurance ...") (internal quotations omitted); Quynh T. Pham, The Future of the National Flood Insurance Program in the Aftermath of Hurricane Katrina, 12 ConN. INS. L.J. 629, 652 (2006) (As of 2006, "of the estimated 72 million owner-occupied structures, only 4.7 million property-owners purchased flood insurance through the NFIP."); Susan Stellin, Reconsidering Flood Insurance, N.Y. TIMES (Nov. 8, 2012), http://www.nytimes.com/2012/11/11/real estate/reconsidering-flood-insurance-after-hurrican-sandy.html?_r=0 [https://perma.cc/J2FGWHPK] (estimating that approximately 18 percent of homeowners in flood-prone areas nationwide have flood insurance).

${ }^{135}$ Letter from Orice M. Williams, Dir., Fin. Mkts. and Cmty. Inv., to the Hon. Spencer Bachus et al., Comm. on Fin. Servs. 3 (Dec. 22, 2008) (GAO-09-188R - Natural Hazard Mitigation and Insurance).

${ }^{136}$ See Earthquake and War Damage Act 1944, 8 GEO. VI, No. 15 (N.Z.); Robert B. Olshansky \& J. David Rogers, Unstable Ground: Landslide Policy in the United States, 13 ECOLOGY L.Q. 939, 989 (1987); Risley, supra note 10, at 1169.

137 See Risley, supra note 10, at 1169.

${ }^{138} I d$. at 1170. 
sidered too difficult and costly to attempt to create actuarially sound premiums regarding specific policyholders' risks of landslide losses. ${ }^{139}$

In France, homeowners insurance must cover natural disasters, including landslides. ${ }^{140}$ The premium for such coverage is a fixed amount. ${ }^{141}$ There is also a premium discount if the municipality in which the property is located has adopted a "prevention of risk plan." 142 A state-sponsored program known as the Caisse Centrale de Reassurance ("CCR"), provides reinsurance to the insurers and receives 50 percent of the premiums collected by the insurers and likewise pays 50 percent of any losses. ${ }^{143}$ France provides an unlimited guarantee of the CCR. ${ }^{144}$

In Belgium, it also is mandatory that homeowners insurance cover natural catastrophes, including landslides. ${ }^{145}$ Unlike the French system, however, the insurers can adjust the premiums based upon the risk of loss presented by individual policyholders. ${ }^{146}$ Approximately 50 percent of the insurers nonetheless charge the same premium to all of their policyholders. ${ }^{147}$ Each individual insurer's risk of losses has a limit, and a state-sponsored "Disaster Fund" covers any losses above the insurer's limit. ${ }^{148}$

Likewise, in Norway, it is mandatory that homeowners insurance cover natural catastrophes, including landslides ${ }^{149}$ The aggregate limit of liability for insurers for any natural disaster event is established by the King. ${ }^{150}$ If a victim of a natural catastrophe does not have insurance, then a state-sponsored program - the National Fund for Natural Damage Assistance-covers the loss. ${ }^{151}$

In Romania, purchasing homeowners insurance to cover landslide losses, along with earthquakes and floods, is mandatory. ${ }^{152}$ Legislation was passed in 2008 to establish an Insurance Pool Against Natural Disasters ("PAID"), which

139 Id.

${ }^{140}$ See, e.g., Michael Faure \& Véronique Bruggeman, Catastrophic Risks and First-Party Insurance, 15 CONN. INS. L.J. 1, 43 (2008); Olivier Moréteau, Policing the Compensation of Victims of Catastrophes: Combining Solidarity and Self-Responsibility, 54 LOY. L. REV. 65, 86 (2008).

141 See Faure \& Bruggeman, supra note 140, at 44.

${ }^{142}$ Id.

${ }^{143}$ Id. at 45; Moréteau, supra note 140, at 89.

${ }^{144}$ See Faure \& Bruggeman, supra note 140, at 45; Moréteau, supra note 140, at 90.

145 See Faure \& Bruggeman, supra note 140, at 45-46.

146 See id. at 46.

${ }^{147} I d$.

${ }^{148} I d$.

149 See Rules for Norwegian Natural Perils Pool, Act No. 70, § 1 (21 Dec. 1979) (Nor.).

150 See Act on Natural Damage Insurance, Act No. 69, § 3 (16 June 1989) (Nor.).

151 Org. for Econ. Co-Operation \& Dev., Financial Management of Large-Scale CATASTROPHES 86-87 (2008).

${ }^{152}$ Ingrid-Mihaela Dragotă et al., Compulsory Insurance for Dwellings in Romania Between Mitigating the Impacts of Natural Disasters and Giving Rise to Social Inequities, 6 AFR. J. Bus. MGMT. 177, 177 (2012). 
is an association comprised of thirteen insurance companies that offer homeowners insurance..$^{153}$ Two separate categories of dwellings were established under the Natural Disaster Insurance Policy. ${ }^{154}$ Premiums are determined based on the building materials of the dwelling. ${ }^{155}$ A dwelling is a Type A building if it is a "building with strength structure of reinforced concrete, metal or wood or with exterior walls made of stone, burnt brick or any materials resulting from heat or chemical treatment." 156 A dwelling identified as a Type B building is a "building with exterior walls of brick or any other material not subject to heat or chemical treatment." ${ }^{157}$ Mandatory insurance for landslides covers only damage to the dwelling. ${ }^{158}$ Any coverage for personal property must be obtained by purchasing additional voluntary insurance. ${ }^{159}$

In Switzerland, insurance companies that provide fire insurance must include coverage for natural catastrophes, including landslides. ${ }^{160}$ It is mandatory for homeowners to purchase fire insurance; therefore, all homeowners have coverage for landslides. ${ }^{161}$ The way individuals acquire this insurance, however, varies among the twenty-six cantons. ${ }^{162}$ Insurance is offered by private insurance companies in seven of the cantons: Geneva, Uri, Schwyz, Ticino, Appenzell Inner Rhodes, Valais, and Obwalden. ${ }^{163}$ These private insurance companies have formed the Natural Perils Pool. ${ }^{164}$ Cantonal building insurance companies, institutions governed by public law that hold a monopoly in their respective cantons, provide insurance for the other nineteen cantons. ${ }^{165}$ Premiums are provided at a uniform rate determined by the Federal Office of Private Insurance ("FOPI"). ${ }^{166}$

In Iceland, under the Iceland Catastrophe Insurance Act of 1975, landslide insurance is included under fire insurance policies, which are mandatory for all

153 Mădălina Giorgiana Mangra et al., Households Insurance - How to Release Catastrophic Risks, 39 ANNALS U. CRAIOVA ECON. SCI. 174, 175 (2011).

${ }^{154}$ Id.

${ }^{155} I d$.

${ }^{156} I d$.

${ }^{157} I d$.

${ }^{158} I d$. at 178

159 Id.

${ }^{160}$ U.S. Gov't Accountability OfFice, GAO-05-199, CATASTrophe Risk: U.S. AND European ApProaches to Insure Natural CATASTrophe AND TERrorism Risks 36 (2005).

161 ORG. FOR ECON. CO-OPERATION \& DEV., supra note 151, at 94.

${ }^{162} I d$.

${ }^{163} I d$.

164 Id.

${ }^{165}$ Id. at $94-95$.

166 Special Requirements for Insurance Class B8: "Fire and Natural Forces", SwISS FED. DEP'T FIN. (Jan. 1, 2006), https://www.finma.ch/FinmaArchiv/bpv/download/e/Spez_Merk blatt_ES_E.pdf [https://perma.cc/4RES-HMN4]. 
homeowners. ${ }^{167}$ Only direct physical losses are covered, and the policy will not ensure a structure that was built in violation of regulations and therefore is more vulnerable to damage by natural perils. ${ }^{168}$ The Iceland Catastrophe Insurance Act also established Iceland Catastrophe Insurance ("ICI"), a state-owned corporation, which provides landslide and other natural perils insurance. ${ }^{169}$ Private insurers that provide fire insurance collect premiums, and then those premiums are provided to ICI in exchange for a collection fee. ${ }^{170}$ Premium rates do not vary by risk, but instead are set at 0.025 percent of the property's value. ${ }^{171}$ Reinsurance for ICI is available on the global market, but ICI has not had to access any of its reinsurance for any natural disaster since its creation. ${ }^{172}$

In Australia, landslide insurance can be purchased from private insurance companies on a voluntary basis. ${ }^{173}$ Many standard homeowners insurance policies that cover natural disasters exclude coverage, however, for landslides except in limited circumstances. ${ }^{174}$ Specifically, landslides are covered only when they occur as a result of another insured event such as an earthquake. ${ }^{175}$ The Australian government does provide, however, partial reimbursement for State and Territory natural-disaster relief for landslides under the Natural Disaster Relief and Recover Arrangements ("NDRRA"). ${ }^{176}$ "[P]ersonal hardship and distress" relief provided under the NDRRA can include grants for things such as housing repairs. ${ }^{177}$ The Australian government also provides direct support

167 ORG. FOR ECON. CO-OPERATION \& DEV., supra note 151, at 69.

${ }^{168} I d$.

${ }^{169} I d$.

${ }^{170} I d$.

${ }^{171} I d$.

${ }^{172} I d$. at 70 .

${ }^{173} I d$. at 44. Other countries such as Sweden, Germany, and Italy provide landslide insurance through voluntary private insurance. In Sweden, landslide coverage is provided by private insurers under homeowners insurance. See, e.g., Sweden Facing Climate Change Threats AND OpPortunities SOU 2007:60, SWEDish COMM'N ON Climate AND VULNERABILITY 593 (2007). Similarly, in Germany, landslide insurance has been provided on a voluntary basis since the Federal Insurance Supervisory Office approved the coverage in 1991. ORG. FOR ECON. Co-OPERATION \& DEV., supra note 151, at 65. Landslide insurance is provided either as a supplement to building insurance or as a separate policy. Id. Likewise, landslide insurance in Italy is not mandated, but it is offered by private insurance companies. Id. at 72; see also id. at 67, 74 (noting there have been failed attempts in Germany and Italy to mandatorily require that landslide losses be covered by insurance).

174 See Org. FOR ECON. Co-OPERATION \& DeV., supra note 151, at 44.

175 See Commonwealth of Austl., Natural Disaster InSuRAnce Review: INQUiRy into FLOOD INSURANCE AND RELATED MATTERS 33 (2011).

176 ORG. FOR ECON. CO-OPERATION \& DEV., supra note 151, at 43.

177 Neil Weeks, Australian Reinsurance Pool Corp., Financial Management of CATASTROPHES IN AustRALIA 6, https://www.oecd.org/finance/insurance/38120102.pdf [http s://perma.cc/E4JZ-4RDM] (last visited July 23, 2016). 
to individuals affected by a natural disaster through Australian Government Disaster Recovery Arrangements (“AGDRA”). ${ }^{178}$

In sum, if it is feasible for landslide losses to be covered by homeowners insurance or state-sponsored programs in numerous countries throughout the world, then one can conclude that they also could be covered in the United States.

\section{E. Resistance Points}

Insurers likely will resist any mandate that requires them to cover landslides under "all risk" homeowners insurance. Insurers will likely argue that a mandate requiring such coverage would be inconsistent with: (1) the concept of freedom of contract ${ }^{179}$ with its attendant notion that insurers should be free to decide what their policies will or will not cover; and (2) the unprofitability of insuring landslide losses due to adverse selection, moral hazard, and correlated risk concerns. Such arguments have carried the day for more than a century. ${ }^{180}$ Although such arguments should no longer have any force for the reasons discussed in this Article, the insurance industry's lobby is strong, as evidenced by the fact that insurance regulators repeatedly have approved policy forms that contain the landslide exclusion (and numerous other exclusions) for decades. ${ }^{181}$

Insurers can also be expected to argue that they would not be permitted to charge actuarially sound premiums for policies that are required to cover landslide losses. Insurers made the same argument when they were not allowed to stop selling homeowners policies that covered wind damage caused by hurricanes in coastal states after multiple hurricanes came ashore in the United States a decade ago. ${ }^{182}$ To be clear, this Article does not propose that insurers be forced to provide landslide coverage for free under "all risk" homeowners insurance. To the contrary, insurers should be allowed to charge a higher premium to reflect the fact that the policies are now insuring an additional risk.

${ }^{178} I d$. at 7.

179 This argument ignores, of course, the fact that insurance policies are contracts of adhesion sold on a take it or leave it basis in which the policyholder has no input regarding the language contained in the policy. See sources cited supra note 51.

180 See sources cited supra note 48.

181 See sample forms supra note 49-50.

${ }^{182}$ See Donald T. Hornstein, Natural Disasters and the Financing of Fat Tails: Lessons from the Economics and Political Economy of Weather-Related Insurance 4 n.9 (Univ. of N.C. Legal Studies Research Paper No. 2249904, 2013), http://ssrn.com/abstract=2249904 [https://perma.cc/7WBP-688P] (describing Allstate's, Farmers Insurance's and Farm Bureau's withdrawal from the insurance markets in Florida and North Carolina when they did not obtain regulatory approval for their requested premium rate increases despite the fact that premium rates already had been increased by 77 percent in Florida between 2001 and 2006); Elisabeth A. Ondera, Testing the Waters: The South Carolina Coastal Captive Insurance Act as Part of a Multifaceted Approach to the Coastal Insurance Conundrum, 59 S.C. L. REv. 599, 600-01 (2008). 
However, the additional risk assumed by insurers would be spread across approximately sixty-nine million homeowners/policyholders with a wide range of risk profiles instead of just a few thousand high-risk stand-alone landslide insurance customers, ${ }^{183}$ so the average premium increase for each policyholder should be quite modest. ${ }^{184}$

One should also expect political opposition from some quarters to any mandate requiring private insurers to cover landslide losses under "all risk" homeowners insurance or to the creation of state-sponsored insurance programs. Some people might characterize a requirement that homeowners policies cover landslide losses or the creation of state-sponsored insurance programs to cover such risks, in combination with the existing laws that effectively require homeowners to purchase homeowners insurance, ${ }^{185}$ as a form of socialism.

The reality, of course, is that the insurance industry already is highly regulated. ${ }^{186}$ Public policy and social concerns regarding the protection of powerless consumers and the compensation of innocent victims are significant drivers of the law for some lines of insurance such as auto and health. Insurers already are regulated by states with respect to the policy language contained in their policy forms, the premium rates they can charge, and the amounts of capital surplus they must maintain. ${ }^{187}$ In addition, states already have created and managed guarantee associations to cover claims submitted to insolvent insurers, and states already have insurance programs for auto drivers who private insurers refuse to accept as customers. ${ }^{188}$ Thus, eliminating the landslide exclusion from homeowners policies or creating state-sponsored insurance programs to cover

183 See supra Part II.D.

${ }^{184}$ In a perfect world, to accomplish the broadest spreading of the risk of landslide losses, nationwide premium rates would be charged with only a modestly higher premium rate being charged to high risk properties (as opposed to attempting to use actuarially based rates on an individual home by home basis) similar to the way the Affordable Care Act allows only limited premium variation based upon factors such as the insured's age and smoking history. See ABRAHAM \& SCHWARCZ, supra note 49, at 354. Homeowners insurance, however, is currently sold, priced and regulated on a state-by-state basis. Consequently, unless that were to change, greater premium subsidization by lower risk homeowners in states where some areas are at higher risks of landslides, such as the West Coast states, necessarily would occur because the risk of landslide losses would be spread directly only to other homeowners in such states. Insurers, however, could still spread their own risks of loss to entities outside of such states through the insurers' corporate relationships with other insurers, reinsurance and catastrophe bonds. See supra Part II.B.3.

185 See INS. INFO. INST., supra note 19.

186 Scales, supra note 17, at 18.

187 See ABRAHAM \& SCHWARCZ, supra note 49, at 126-28, 142-46; JERRY \& RICHMOND, supra note 16 , at $90-94$.

188 See ABRAHAM \& SCHWARCZ, supra note 49, at 122-23; ABRAHAM, supra note 85, at 771; see also Spencer L. Kimball \& Noreen J. Parrett, Creation of the Guaranty Association System, 19 J. Ins. REG. 259, 259-60 (2000). 
landslide losses would be simply one of many ways in which states can and do regulate the insurance industry.

Other people who stress individualism over community likely will object to including mandatory coverage for landslides under homeowners insurance or creating state-sponsored insurance programs if it results in any amount of premium subsidization. ${ }^{189}$ Under the proposals in this Article, it is possible that people who live in extremely low-risk areas would subsidize those who live in high-risk areas because not all of the numerous potential risk classifications for the peril of landslide would be factored into the premiums for the higher-risk homes. ${ }^{190}$ Addressing all of the potential risk variables for landslide risk would be unnecessary if coverage for landslides were bundled together with all of the other covered perils, however. Each policyholder's premium would be based upon her home's overall risk profile for all covered perils, not just with respect to any particular peril. In such circumstances, because the premium calculation would be based upon a broad array of factors, it is inevitable that some premium subsidization would occur. Such a scenario would not, however, be any different from how insurance operates today. Coverage for many risks are already provided under homeowners policies regardless of whether the policyholder actually needs or wants coverage for all of the covered risks. Therefore, policyholders already are paying for coverage they do not want or need, thus subsidizing other policyholders in the same pool of insureds who do want and need that coverage. That, in fact, is one of the very reasons why landslide coverage should be included in "all risk" homeowners policies. Bundling coverage for landslides with other perils would make insurance for landslide losses more affordable and would dramatically increase participation rates.

${ }^{189}$ With respect to another natural catastrophic risk, flooding, many people probably do not realize that they are subsidizing flood losses even though they do not have flood insurance. The NFIP, which is sold as stand-alone named peril insurance for just flood losses, currently is being subsidized by taxpayers in the amount of approximately $\$ 24$ billion even though most people are uninsured for flood losses. See U.S. Gov'T ACCOUNTABILITY OfFICE, supra note 133 . Further, government bailouts of property owners in areas devastated by natural catastrophes such as Hurricanes Katrina and Sandy are another form of public subsidization of individuals' losses.

190 An example of a state where lower risk homeowners currently subsidize higher risk homeowners insurance premium rates for certain catastrophic perils is Florida. The dominant homeowners insurance provider in Florida is Citizens Property Insurance Corporation, a state-sponsored program. Cole et al., supra note 120 , at 269. It offers property insurance to homeowners in Florida to cover hurricane damage at premium rates significantly lower than private insurers. $I d$. It is able to do so because: (1) it does not need to provide an adequate return to investors; (2) it is tax exempt; (3) it does not need to raise excessive amounts of capital to pre-fund losses because it has the ability to do post-loss assessments; and (4) it is reinsured by a state-sponsored reinsurer, the Florida Hurricane Catastrophe Fund. See id. at 267-71. Under the program, the premium rates charged to coastal residents are subsidized by inland residents to a minor extent. $I d$. at 280-85. 


\section{CONCLUSION}

Despite the fact that landslides account for approximately $\$ 3.5$ billion in damage annually, only a few American homeowners in a few states have insurance that covers landslide losses. The landslide insurance coverage that is available is very expensive and often does not even cover a significant amount of the loss a typical landslide victim suffers. That is not the case in many countries around the world, which have recognized that the justifications historically used to allow insurers to exclude coverage for natural catastrophes such as landslides-adverse selection, moral hazard, and correlated risks - have little force today.

Unlike other types of catastrophes that cause widespread damage to hundreds or thousands of people at the same time, landslides typically impact a much smaller geographic area and number of people when they occur, so the argument that landslide losses are uninsurable, correlated risks is untenable. In addition, insurance is now a global business by which the risk of loss for any individual or group of policyholders in any given geographic area is spread across a worldwide pool of premium-paying insureds and investors through reinsurance and catastrophe bonds. Consequently, homeowners insurance could cover landslides with little risk of insurer insolvencies occurring as a result. Alternatively, or in combination with private insurance, state-sponsored insurance programs could be created so landslides cease to be uninsured catastrophes in America. 